Latutrie B, Ross P-S (2019) Transition zone between the upper diatreme and lower diatreme: origin and significance at Round Butte, Hopi Buttes volcanic field, Navajo Nation, Arizona. Bulletin of Volcanology 81(4):26

\title{
Transition zone between the upper diatreme and lower diatreme: origin and significance at Round Butte, Hopi Buttes volcanic field, Navajo Nation, Arizona
}

\author{
Benjamin Latutrie*, Pierre-Simon Ross \\ Institut national de la recherche scientifique, Centre Eau Terre Environnement, 490 rue de la Couronne, \\ Québec (QC), G1K 9A9, Canada \\ * Corresponding author \\ E-mail addresses: Benjamin.Latutrie@ete.inrs.ca (B. Latutrie), rossps@ete.inrs.ca (P-S. Ross)
}

\section{Keywords:}

maar-diatreme, crater, upper diatreme, lower diatreme, transition zone

\begin{abstract}
Round Butte is a small but complex Miocene diatreme that crops out $\sim 190 \mathrm{~m}$ below the pre-eruptive surface, in the southeastern part of the Hopi Buttes volcanic field. Erosional remnants consist of a diatreme 170-190 $\mathrm{m}$ in diameter, of which the central 130-150 $\mathrm{m}$ is well-exposed in a massif featuring 20-30 m high sub-vertical cliffs, and a $50 \mathrm{~cm}$-thick basanite dike. Field mapping allowed us to define three main groups of pyroclastic rocks in the diatreme: undisturbed beds, disturbed beds and non-bedded rocks. Pyroclastic rocks range in grain size from coarse tuff to tuff breccia and in componentry from juvenile-rich to lithic-rich, with a dominance of heterolithic lapilli tuffs. Rocks from the undisturbed bedded pyroclastic group are present above an unconformity found all around the massif, whereas the disturbed bedded and the non-bedded pyroclastic groups are always found below it. This unconformity was previously understood as the contact between the upper and the lower diatreme. The undisturbed beds above the unconformity indeed compose the upper diatreme, but the assemblage of non-bedded rocks (invasive columns) and disturbed beds (residual columns) below it are not typical of the lower diatreme. Instead, they represent a transition zone between the upper and lower diatreme. Such a transition zone also occurs in other diatremes, it is important genetically, and we propose to add it to the general model of maar-diatreme volcanoes.
\end{abstract}

\section{Introduction}

Maar-diatremes are small, dominantly phreatomagmatic volcanoes that excavate country rocks to form a funnel-shape structure called a diatreme (e.g., Lorenz 1986; White and Ross 2011; Valentine and White 2012; Ross et al. 2017). Eruptive processes occurring in the diatreme and the underlying root zone have never been directly observed, being subterranean, but have been interpreted based on a combination of documentation of historical maar eruptions (Thomas 1888; Moore 1967; Kienle et al. 1980; Self et al. 1980; Ort et al. 2018), field work on maar ejecta ring and diatreme pyroclastic deposits and rocks (e.g., White 1991; Ross et al. 2008a; Lefebvre et al. 2013; Bélanger and Ross 2018), and 
experiments at various scales (Zimanowski et al. 1997; Kurszlaukis et al. 1998; Ross et al. 2008b, 2008c, 2013; Valentine et al. 2012, 2015; Taddeucci et al. 2013; Graettinger et al. 2015). Part of the complexity of diatremes comes from their formation from hundreds to thousands of explosions (Self et al. 1980; White 1991; Lorenz 2007; Valentine et al. 2014). Another complicating factor is that phreatomagmatic and magmatic vents can be active at the same time, as observed at Ukinrek east maar in 1977 (Kienle et al. 1980; Self et al. 1980; Ort et al. 2018).

Due to exposure constraints, most maar-diatreme studies focus on a specific part of the volcano, such as the ejecta ring and crater (e.g., Kienle et al. 1980; White 1991; Vazquez and Ort 2006; Ort and Carrasco-Núñez 2009; Austin-Erickson et al. 2011; Valentine et al. 2015; Graettinger 2018), the upper diatreme (e.g., White 1991; White and Ross 2011; Delpit et al. 2014), the lower diatreme (e.g., White 1991; Lefebvre et al. 2013, 2016; Bélanger and Ross 2018), or rarely, the root zone (Clement 1982; Lorenz and Kurszlaukis 2007) or the intrusive plumbing system $(\mathrm{Re}$ et al. 2015, 2016; Muirhead et al. 2016; Le Corvec et al. 2018). The origin of the lower diatreme is still strongly debated in the literature (see discussion in Bélanger and Ross 2018). The contact between the lower and upper diatreme is rarely exposed (Kurszlaukis et al. 2009) and has only been documented in detail at a few localities (e.g., Cathedral Cliff diatreme: Bélanger and Ross 2018). Some workers have emphasized a major contact in the diatremes they studied, with deposits above and below formed by different processes or eruptive styles, at different times, with the lower diatreme being older than the upper diatreme (e.g., Porritt et al. 2008; Gernon et al. 2008, 2013). The importance of studying the upper/lower diatreme transition, in particular its morphology, is to understand whether the upper and lower parts have a disconnected history, or if they formed simultaneously. If the upper and lower diatreme formed at least partly simultaneously, then bedded pyroclastic rocks within the upper diatreme - the origin of which is typically clearer - can be used to interpret non-bedded pyroclastic rocks of the lower diatreme.
This transition from upper to lower diatreme is exposed at Round Butte, a small Miocene diatreme in the Hopi Buttes volcanic field (HBVF), Navajo Nation, Arizona (USA). This locality has been known for several decades because of the quality of exposure and the complexity of its pyroclastic rocks (White 1991; White and Ross 2011), but no detailed study was previously conducted. In this paper, we present the results of detailed mapping of the cliffs at Round Butte. We provide new insights on the architecture of the diatreme deposits and discuss the following topics: crater excavation and infilling; the link between the upper and the lower diatreme; the formation processes of the lower diatreme; and the origin and significance of the upper/lower transition zone.

\section{Geological setting}

The HBVF is located in the south central portion of the Colorado Plateau (Williams 1936) and was active during the Miocene from 8 to $6.5 \mathrm{Ma}$ (Vazquez and Ort 2006). At the time of the eruptive activity, playas and ponds occupied the region (White 1990). This waterrich environment in the Miocene permitted magma-water interactions and produced numerous phreatomagmatic explosions (White 1991; Hooten and Ort 2002; Lefebvre et al. 2013). The four main sedimentary formations in the HBVF region are, from top to bottom, the Bidahochi Formation (Miocene), the Moenave Formation (Lower Jurassic), the Chinle Formation (Upper Triassic) and the Moenkopi Formation (Lower Triassic) (Billingsley et al. 2013). The Chinle formation is the thickest and is divided into three members, namely the Owl Rock Member, the Petrified Forest Member and the Shinarump Member (Fig. 1).

The HBVF covers an area of about $2300 \mathrm{~km}^{2}$ and contains more than 300 volcanic structures (Fig. 1, Hack 1942; White 1991). Igneous remnants are mainly maar-diatremes (e.g., Williams 1936; White 1989; 1991; Hooten 1999), dikes ( $\operatorname{Re}$ et al. 2015; 2016; Muirhead et al. 2016; van Otterloo et al. 2018) and lava flows (Williams 1936, Vazquez 1998), but also scoria cones (Williams 1936; White 1990; Vazquez 1998). Maar-diatreme volcanoes in the HBVF are exceptionally preserved, without tectonic deformation and 
metamorphism (Gilbert et al. 2007). The erosion level increases from north to south, exposing progressively older Colorado Plateau sedimentary rocks (Fig. 1, Billingsley et al. 2013). This corresponds to progressively deeper levels in maar-diatreme structures, making the HBVF an outstanding place for maar-diatreme studies from the ejecta ring (e.g.. Teshim Maar, White 1991) to the lower diatreme (e.g. Standing Rocks, Lefebvre et al. 2013; 2016). Round Butte is located in the southeastern part of the HBVF (Fig. 1).

\section{Methods}

One month of field work was carried out at Round Butte. We mapped the sub-vertical cliffs (20 to $30 \mathrm{~m}$ high) using nine high-resolution panoramic photographs. Their distribution is shown on the Round Butte geological map (Fig. 2 ) as figure numbers in the paper (Figs. 3 to 7) or in the Online Resource 1 (Figs. S1.1 to S1.4). The photographs were printed, then geological contacts were traced in the field, with the help of binoculars and cliff-base detailed observations. For each mapped unit, we obtained meter-scale observations, lithological descriptions, compositional measurements and a hand sample. Our visual descriptions took into account the semi-quantitative lithic vs juvenile clast proportions and their mean grain size (ash, fine to coarse lapilli and blocks and bombs). Pyroclastic rocks were named according to the White and Houghton (2006) nomenclature. This allowed us to associate the described unit to a facies (all facies codes in Tables 1, 2,3). Based on the hand sample collection, 32 thin sections were prepared to characterize the matrix (particles smaller than $4 \mathrm{~mm}$ ) of the pyroclastic rocks with a petrographic microscope.

Finally, for geochemical analyses, we collected five samples of juvenile blocks and bombs in different pyroclastic facies and one sample from the northwest dike. The geochemical methods and results are presented in Online Resource 2.

\section{Results}

The plain around Round Butte exposes Owl Rock Member sedimentary rocks $\sim 190$ m below the pre-eruptive surface (Billingsley et al.
2013). Round Butte is a diatreme 170 to $190 \mathrm{~m}$ in diameter at the current level of exposure, of which the central 130-150 $\mathrm{m}$ is well-exposed in a massif featuring 20-30 m high sub-vertical cliffs. The outer portion of the diatreme is very poorly to moderately well-exposed at the same elevation as the surrounding country rocks. Northwest of the diatreme is a $\sim 90 \mathrm{~m}$ long coherent basanite dike, up to $50 \mathrm{~cm}$ thick, extending in the northwest direction (Fig. 2).

Detailed mapping of the whole circumference of the massif is presented here (Figs. 3 to 7) and in Online Resource 1 (Figs. $\mathrm{S} 1.1$ to S1.4). Based on this mapping we have defined five groups of facies: (1) undisturbed bedded pyroclastic rocks ( $25 \%$ of the total area of the panoramic photographs), (2) disturbed bedded pyroclastic rocks ( 38\%), (3) nonbedded pyroclastic rocks $(\sim 30 \%)$, (4) megablocks $(\sim 3 \%)$ and (5) debris avalanche deposits $(\sim 4 \%)$. The first three main facies groups make up the bulk of the exposure and we focus on those groups here; information on the megablocks and debris avalanche deposits will be presented elsewhere. An unconformity clearly separates the undisturbed bedded pyroclastic group (above it) from the disturbed bedded pyroclastic group and the non-bedded pyroclastic group (below it). This unconformity can be followed all around the diatreme; it is mostly sub-horizontal (Figs. 3, 4, S1.1, S1.3) but locally becomes irregular (Figs. 3, 6, 7).

\section{Undisturbed bedded pyroclastic rocks}

The upper part of the massif typically exposes well-preserved, undisturbed bedded pyroclastic rocks. These rocks are discontinuous and display a mean thickness around $5 \mathrm{~m}$ (Figs. 3, 4, $\mathrm{S} 1.3, \mathrm{~S} 1.4)$. This facies group is thickest in the southwest part of the massif (10-20 m thick, Figs. 3, 5) and disappears in the northeast part (Figs. 4, S1.3). Five different undisturbed bedded pyroclastic facies are distinguished on the basis of their componentry, grain size and structures (facies codes in Table 1). All five facies form well-defined sub-horizontal beds or lenses ranging in thickness from centimeters to several meters (Fig. 8). Grainsize is coarse tuff to tuff breccia and componentry ranges from lithic-rich to juvenile-rich. 


\section{Disturbed bedded pyroclastic rocks}

One of the facies groups located below the unconformity consists of variably disturbed bedded pyroclastic rocks (Figs. 3 to 7 and S1.1 to S1.4). This group has a concordant contact with debris avalanche deposits (Figs. 3, 5, 7) and mostly sub-vertical contacts with nonbedded pyroclastic rocks (Figs. 3, 4, 7, S1.1, S1.3). Those sub-vertical contacts create an alternation of non-bedded pyroclastic rocks with disturbed bedded pyroclastic rocks that form column-like units. On the east side of the massif, disturbed pyroclastic rocks occupy most of the face (Fig. S1.3). In this facies group in general, the bedding is mostly diffuse to destroyed (Figs. 7, S1.3) but in some places it is better preserved (Figs. 3, 4, 6). Beds are subhorizontal (Figs. 3, 6, 9) to steeply dipping (Fig. S1.3), with thicknesses from centimeters to almost $10 \mathrm{~m}$. The bedding is locally swirly in the pyroclastic rocks (Figs. S1.2, S1.3) and Bidahochi megablocks can also be highly deformed (Figs. 3, 9a). Flame structures are seen locally, at the bottom contact of a b(c)LTj unit (Fig. S1.1). Disturbed bedded pyroclastic rocks are composed of five different facies, ranging from lithic-rich to juvenile rich and from coarse tuff to tuff breccia (facies codes in Table 2).

\section{Non-bedded pyroclastic rocks}

Rocks of the non-bedded pyroclastic group are separated in seven different facies (facies codes in Table 3) and are mainly located in the bottom part of the cliffs (under the unconformity). However, in figure 3 the biggest non-bedded unit goes to the top of the outcrop. This group is mainly in contact with the disturbed bedded pyroclastic group (Figs. 3, 4, 7, S1.1, S1.3), and with debris avalanche deposits (Fig. 3, nTB1 facies). The contacts between the non-bedded group and other facies are typically sub-vertical to steep, but locally flatten when the top of a column occurs (Fig. 3, nTBh column on the right side; two non-bedded columns in Fig. $\mathrm{S} 1.3)$. The 1 to $20 \mathrm{~m}$-wide, column-like units are composed by medium lapilli tuff to tuff breccia with a variable, but mainly heterolithic, componentry (Fig. 10).

\section{Faults in the pyroclastic rocks}

Faults are present in the western part of the massif (Figs. 5, 6, 7) and are particularly visible in the undisturbed bedded group. Faults must continue below the unconformity in the disturbed bedded and non-bedded groups because those deposits are older, but we were not always able to follow them, due to a lack of clear marker beds to show offsets. These faults seem to have an arcuate 3D shape, steep dips and a normal slip component. Their orientation is difficult to evaluate, but the general impression is that the fault planes are subparallel to the cliffs. Most of the faults on the west side of the diatreme have a downward movement toward the southwest part of the diatreme (Figs 5, 6, 7). In the south face the unconformity is lower on the left side of the big nTBh column than on its right side. This could be explained by a fault with a downward movement toward the southwest part of the diatreme within this big nTBh column or within the rocks that were there before the column was emplaced (Fig. 3).

\section{Juvenile clasts}

In the field, we defined three main families of juvenile clasts based on their color: (1) brown, (2) light grey, and (3) medium grey to black. Brown juvenile clasts are smaller on average (ash to $<1 \mathrm{~cm}$ ), appear less abundant than other types in the field, and have angular to subrounded shapes (Figs. 11a, 11b, 11c). Light grey juvenile clasts are slightly bigger than the brown ones, ranging in size from coarse ash to several $\mathrm{cm}$ and rarely to block/bomb sizes. They display angular to sub-round shapes and are often friable due to alteration. Medium grey to black juvenile fragments reach larger sizes (up to $\sim 2 \mathrm{~m}$ ) and have mainly sub-rounded to amoeboid, to locally angular, shapes (Figs. 11a, $11 \mathrm{~b}, 11 \mathrm{c})$.

Under the microscope, juvenile clasts of all families contain $10-15 \%$ of $0.5-5 \mathrm{~mm}$ phenocrysts of euhedral clinopyroxene, traces of euhedral to slightly resorbed phlogopite up to 
$1 \mathrm{~cm}$ across and traces of euhedral olivine, 0.5$3 \mathrm{~mm}$ across, now slightly to highly serpentinized. The groundmass is mainly composed of clinopyroxene microlites and microphenocrysts, plus "glass". This "glass" component ranges from tachylite in the medium grey to black family to former sideromelane, now altered to palagonite and clays, in the brown family. Clasts of all families are nonvesicular to moderately vesicular according to the Houghton and Wilson (1989) scheme, with a vesicularity ranging from $0 \%$ to $60 \%$ overall, although most clasts have $15-25 \%$ vesicles (Figs. 11a, 11b, 11c). Vesicles are round to elongate and often filled with calcite or zeolites. Evidence of recycling is recorded in cored and loaded clasts (Figs. 11a, 11d; Lefebvre et al. 2013). Free fragmented crystals of clinopyroxene, phlogopite and rare serpentinized olivine appear in the massif as juvenile components with the same size and morphology as described within the juvenile fragments (Figs. 11a, 11b).

\section{Interpretation: origin of Round Butte rocks and features}

\section{A maar-diatreme volcano}

We interpret the Round Butte exposures as representing the diatreme portion of a small maar-diatreme volcano (Lorenz 1986; White 1991; White and Ross 2011; Valentine and White 2012; Lefebvre et al. 2013, 2016) based on the following evidence:

- At the current level of exposure, the pyroclastic rocks are surrounded by older sedimentary country rocks (Owl Rock Member, $190 \mathrm{~m}$ below the preeruptive surface);

- $\quad$ The mapped pyroclastic rocks form an elliptical body in map view (Fig. 2);

- The pyroclastic rocks have some features typical of phreatomagmatic diatremes elsewhere (e.g., White 1991; Lefebvre et al. 2013; Bélanger and Ross 2018): surge deposits (e.g., facies bT2), cross-cutting sub-vertical columns of non-bedded pyroclastic rocks, presence of megablocks from the host sedimentary rocks and megablocks of pyroclastic rocks, and for many pyroclastic rocks, poor sorting and a high lithic content;

- Several maar ejecta rings and maar crater infills are documented further north in the HBVF (White 1991; Lefebvre et al. 2013, 2016).

The current outcrop at Round Butte contains significant proportions of both bedded pyroclastic rocks (undisturbed + disturbed $=$ $63 \%)$ and non-bedded pyroclastic rocks $(30 \%)$ and has been previously interpreted as featuring the contact between the upper diatreme and the lower diatreme (White 1991; White and Ross 2011).

\section{Formation of juvenile clasts}

Juvenile clasts formed when a rising basanite intrusion was fragmented, both in the country rocks and in the evolving diatreme (Fig. S2.1). The NW dike (Fig. 2) may be an unfragmented expression of this feeder intrusion, based on geochemistry (Online Resource 2, Fig. S2.3). In the field and hand samples, we found three families of juvenile clasts in the diatreme, namely brown, light grey, and medium grey to black ones. Under the microscope, all three families share the same phenocrysts, microlites and range of vesicularities, strongly suggesting that they were derived from the same parental magma. Where they differ is in the character of their groundmass. The macroscopically brown clasts contain palagonitized sideromelane whereas the macroscopically medium grey to black ones contain tachylite. The light grey juvenile clasts are also palagonitized, but may have consisted of material transitional between sideromelane and tachylite before alteration (e.g., Furnes 1975; Stroncik and Schmincke 2002). Brown and light grey juvenile fragments are less abundant overall, smaller on average, and more frequently have an angular shape, compared to the medium grey to black ones. Rapid magma cooling, probably in the presence of water, produced sideromelane, and slower cooling produced tachylite (Fisher and Schmincke 1984; White and Houghton 2015).

\section{Syn-eruptive faults and subsidence}


Faults have been observed within other diatremes and feature prominently in the Lorenz (1986) model. These faults are restricted to the diatreme, i.e. they do not affect the country rocks outside the diatreme. The syn-eruptive timing of at least some of the faults at Round Butte is illustrated on figure 6 , where the final bLTj unit is not affected, in contrast to the underlying beds which have sudden lateral thickness changes. Most of the faults have a downward movement toward the southwest part of the diatreme. This points to an area of maximum downward movement in the SW portion of the diatreme, where the infill of the undisturbed bedded group is also the thickest. Our preferred interpretation for these faults is that explosions in the southwest part of the diatreme sent material upwards. Some fell back into the crater, and some was expelled towards the ejecta ring. This removal of material from the diatreme allowed the remaining and newly deposited material to subside, by a few metres, in an asymmetric way. Some of these explosions would have formed the wide unit from the nTBh facies on the south face (Fig. 3).

The small syn-eruptive faults represent a minor form of subsidence. Beyond that, there is no evidence of a large amount of subsidence, such as saucer-shaped beds, in the undisturbed bedded group. However, the relatively coarsegrained nature of the lithofacies, and the large thickness of some beds, would make saucershaped bedding more difficult to identify compared to what is the case at some other diatremes (Delpit et al. 2014; Bélanger and Ross 2018).

\section{Undisturbed bedded pyroclastic rocks}

The undisturbed bedded pyroclastic group is composed of five facies and represents $25 \%$ of the exposure at Round Butte (Table 1). These rocks always occur above the unconformity and are thought to have been emplaced late in the eruptive history of the volcano. Depending on the facies, the sub-horizontal beds are centimeters to several meters in thickness. Such bedded deposits are typical of the upper diatreme (White 1991; White and Ross 2011). We consider that these rocks were emplaced more or less where we see them today, at a depth of $<170 \mathrm{~m}$ below the pre-eruptive surface, because no strong evidence of subsidence is observable at Round Butte.

The numerous beds in the undisturbed bedded group imply multiple explosions. The main facies in terms of area exposed consist of lapilli tuff to tuff breccia (bLTj, bLTh2 and bTBm), interbedded with minor thin-bedded coarse tuff to fine lapilli tuff (bT2, Fig. 8a, 8c), and one unit of lapillistone (bLS, Fig. 8e). Componentry in the undisturbed bedded group is mainly juvenile-rich to heterolithic, with local Moenave-rich lenses or thick beds (bTBm, Fig. $5,8 \mathrm{a}, 8 \mathrm{~d})$. We interpret all the facies in the undisturbed bedded group as phreatomagmatic, except for bLS.

The bT2 facies is thinly bedded and characterised by alternating finer and coarser layers with local low angle cross-bedding and dunes (Fig. 4, 8a, 8c). This facies is interpreted as pyroclastic surge deposits (Sohn and Chough 1989; White and Ross 2011). Deposits with bT2-like characteristics are typical of the medial parts of maar ejecta rings (e.g., White 1991; Sohn 1996; Vazquez and Ort 2006) but are also sometimes encountered in the upper parts of diatremes, where the crater is large enough to allow laterally moving currents (e.g., White and Ross 2011; Delpit et al. 2014; Bélanger and Ross 2018). Since the Round Butte crater was rather narrow $(\sim 180 \mathrm{~m}$ in diameter at $\sim 190 \mathrm{~m}$ in depth), the bT2 facies in the SW corner of the massif may originate from explosions on the opposite side of the crater. Phreatomagmatic fallout deposits may also be present within this facies.

The main undisturbed bedded facies (bLTj) is coarser grained than bT2 and the beds are thicker, more diffuse and sometimes lenticular in shape (Figs. 3, 8a). Bomb sags are locally observed. These features suggest proximal deposits of pyroclastic density currents (PDCs), fallback (Ross et al. 2013) or proximal fallout. On the south face of Round Butte, bLTj has a gradational lateral transition into non-bedded rocks of the nTBh facies (Fig. 3 ), suggesting that the later unit may represent one of the vents for the bLTj facies.

The bLTh2 and bTBm facies are internally structureless to very diffusely bedded. They form lenses or thick beds. We interpret these two facies as very proximal deposits from PDCs or as fallback deposits. The 
bTBm facies presents an enrichment in Moenave blocks that fell from the crater walls during explosive activity.

The least abundant facies of this group (bLS) is preserved at the top of the massif in the western portion (Fig. 7). This facies is the best sorted of the massif, the least rich in ash $(<25 \%)$ and is composed of lapilli and blocks/bombs of dark grey to black juvenile clasts. It seems to be rich in scoria but because of its high position in the outcrop, we were unable to quantify clast proportions. To produce coarse clasts and less ash, fragmentation needs to be less efficient than for the rest of the bedded facies. We infer a magmatic fragmentation similar to a strombolian style, or a very weak magma-water interaction, to produce this facies (Ripepe et al. 2008).

\section{Disturbed bedded pyroclastic rocks}

Rocks of the disturbed bedded pyroclastic group cover $38 \%$ of the exposure at Round Butte. They are similar to those of the undisturbed bedded group in terms of grain size and componentry, but they display various degrees of deformation and disturbance, and they occur below the unconformity. This group is composed of five different facies with one dominant facies (bLTh1) and four minor ones (Table 2). All of these facies are interpreted as phreatomagmatic.

Because bLTh1 deposits are still bedded, or were originally bedded, we interpret them as emplaced on the bottom of the syneruptive crater. Upon deposition, they were likely similar in aspect to those of the betterpreserved bLTj (from the undisturbed bedded pyroclastic group). This suggests that the same volcanic processes (PDCs, fallout and fallback) were responsible for initial deposition of the bLTh1 facies. The bT1 facies found locally on the north side of the massif (Fig. 4) still presents primary features (bedding and grain size) that are comparable to those described for undisturbed bT2 facies, meaning they share a common origin.

The thickest bed of the massif $(\sim 10 \mathrm{~m})$ is internally structureless and corresponds to the bLTb facies (Fig. 6). Its origin is not clear. The bTB1 facies is the disturbed equivalent of bTBm facies (from the undisturbed bedded pyroclastic group). It forms small domains or lenses rich in Bidahochi and Moenave blocks that fell inside the crater during activity (Figs. 3, S1.1). Rare Owl Rock and Moenkopi blocks are present. The $b(c) L T j$ facies is only found on the SE side of the massif, it forms a thick bed that grades laterally into a non-bedded column with the same componentry (Fig. S1.1, n(c)LTj facies). We assume that the bed is the erupted (fallback) equivalent to the column, which itself was formed by one or several juvenile-rich debris jet(s).

The bedding disturbance (in the disturbed bedded pyroclastic group) is likely due to a range of processes:

- syn-eruptive subsidence might have played a role (e.g., Delpit et al. 2014; Bélanger and Ross 2018), although there is no strong evidence for it, apart from the normal faults on the west side;

- liquefaction is manifested in the flame structures seen on the southeast side of the diatreme (bottom contact of b(c)LTj, Fig. S1.1), and perhaps in the swirly beds and Bidahochi megablocks seen in various places (Figs. 3, 9a, S1.3); such features are absent from the undisturbed bedded group, suggesting that liquefaction in the disturbed bedded pyroclastic group occurred during the eruption;

- debris jets due to phreatomagmatic explosions in the diatreme (White 1991; White and McClintock 2001; Ross and White 2006; Ross et al. 2008b, 2008c; Lefebvre et al. 2013) emplaced the non-bedded invasive columns and disturbed the surrounding host, forming residual columns.

Debris jets are thought to be the most important process to explain the bedding disturbance. With periodic injections of debris jets, the host bedded pyroclastic deposits got more and more disturbed until the bedding was largely destroyed within what became residual columns. The disturbed bedded pyroclastic rocks are genetically transitional between the undisturbed bedded pyroclastic rocks and the non-bedded pyroclastic rocks. They are conceptually analogous to the "broken beds" described at Cathedral Cliff by Bélanger and 
Ross (2018), although the coarser grained, perhaps less cohesive nature of the bedded pyroclastic rocks at Round Butte means that the "broken" aspect is much less visible (but see Fig. S1.3).

\section{Non-bedded pyroclastic rocks}

Non-bedded pyroclastic rocks are well represented at Round Butte, with $30 \%$ of the total exposed area of the massif. They are separated into seven facies (Table 3). Nonbedded facies are coarser on average than those of the undisturbed and disturbed bedded groups, with grain sizes ranging from medium lapilli tuff to tuff breccia. Componentry is mainly heterolithic and quite similar to the two other groups overall, with juvenile-rich to lithic-rich units. Non-bedded pyroclastic rocks seem richer in juvenile clasts than the other facies groups.

We consider that non-bedded pyroclastic columns are formed from the passage of debris jets, so we call the deposits "invasive columns". The pulsating activity of maar-diatreme volcanoes is related to a multitude of subterranean phreatomagmatic explosions (e.g., White 1991; White and Ross 2011; Lefebvre et al. 2013; Bélanger and Ross 2018). Explosions can occur everywhere inside the diatreme (White and Ross 2011; Valentine et al. 2014) generating upward moving jets composed of pyroclasts (juvenile and lithic), gas and perhaps liquid water (Ross and White 2006). Debris jets can reach the surface to generate a plume or eruptive jet that rises above the crater, but some debris jets remain confined inside the diatreme (Ross et al. 2008b, 2008c), meaning that the top of the invasive column will be visible (e.g., Fig. 3, nTBh invasive column on the right side; see also Fig. S1.3).

Very wide non-bedded units, from the nTBh facies (Fig. 3), the n(c)LTj facies (Fig. 4) and the $\mathrm{n}(\mathrm{mc}) \mathrm{LTh} 2$ facies (Fig. S1.4), are thought to be composite and formed by many debris jets of similar componentries, along with total destruction and homogenization of formerly bedded pyroclastic material. Some of the material involved in the debris jets would be newly generated fragments (mostly juvenile ones from the fragmenting intrusion), but a significant portion of each debris jet will consist of pre-existing diatreme infill. Therefore, debris jets are an efficient mechanism to disturb and homogenise bedded deposits to progressively form non-bedded deposits that compose the lower diatreme (Bélanger and Ross 2018).

\section{The unconformity: morphology and origin}

The unconformity seen all around the diatreme is an important component of its architecture. In some places, the unconformity truncates the top of invasive columns (Figs. 3, 7, S1.1), showing that it formed during a period of crater excavation, at a time when the diatreme was already filled by disturbed bedded pyroclastic deposits and non-bedded pyroclastic deposits. Therefore, this unconformity corresponds to one of the crater floor positions during Round Butte activity.

\section{Round Butte evolution model}

We present in figure 12 our model showing the evolution of the diatreme, drawn in such a way that the final cartoon looks like the south face of Round Butte (Fig. 3), since that face displays all five facies groups, including the three main facies groups which are the focus of this paper.

\section{Initial crater and proto-diatreme}

The recent literature mentions dikes, sills, sheets and plugs as possible feeders of maardiatreme volcanoes (e.g. Re et al. 2015, 2016; Muirhead 2016; Le Corvec et al. 2018). In our model, for simplicity, we consider a dike, likely less than $1 \mathrm{~m}$ thick, as the feeder of the Round Butte diatreme. This is based on the $50 \mathrm{~cm}$-thick basanite dike located NW of the massif (Fig. 2) and on measured dikes elsewhere in the HBVF (Re et al. 2015, 2016; Muirhead 2016). This feeder dike rose through the Colorado Plateau sedimentary rocks and interacted explosively to non-explosively with groundwater or wet sediments. In the region, aquifers were probably horizontal, following specific porous and permeable sedimentary layers such as the Moenave Formation, the Shinarump Member or the Moenkopi Formation (Hart et al. 2002). At the time of the eruptive activity, the Bidahochi 
Formation (mainly mudstone in the Round Butte area) was still being deposited regionally and was water-saturated (White 1990, 1991; Billingsley et al. 2013). Mudstones from the Bidahochi Formation likely had a low permeability, but incorporation of wet Bidahochi material within dikes and diatremes is a possible source of water for phreatomagmatic activity (e.g., White 1991, 1996; Hooten and Ort 2002).

The initial crater at Round Butte was likely created by explosions close to the surface in the Bidahochi Formation (Fig. 12a; Valentine et al. 2014). Deposits that filled the initial crater are here called proto-diatreme and these deposits (as well as the initial ejecta ring) are inferred to have been Bidahochi-rich ). At the same time, other explosions may have occurred at deeper levels (perhaps in the Moenave Formation, the Shinarump Member or the Moenkopi Formation) fragmenting country rocks around the dike at depth (Fig. 12a).

\section{First cycle of excavation and infilling}

An intense explosive phase widened and deepened the crater, as also proposed by Lefebvre et al. (2013) for West Standing Rocks in the HBVF. Eventually, the Round Butte crater floor reached its deepest level (Fig. 12b). The details of how this happened, and the nature of the diatreme infill at that stage, are unknown, since these deposits are located below the current ground level. A major excavation step is necessary in the model to have subsequently formed deposits (from the disturbed bedded pyroclastic group) filling a deep crater. One or many stages of crater excavation are also supported by the relatively low average lithic contents of the diatreme, in particular the low content of Bidahochi clasts.

This first excavation phase is inferred to have dug a relatively deep crater. At this stage, the root zone is inferred to have reached the Petrified Forest Member and the bottom of the crater was perhaps in the Owl Rock Member. We consider that the crater floor was deeper than the current plain (itself $\sim 190 \mathrm{~m}$ below the pre-eruptive surface) because we found bedded pyroclastic rocks that seem to go below that (disturbed bedded group; Fig. 3).
During the major excavation phase and after it, pyroclastic material was deposited on the crater floor, the crater widened due to slumping of the walls (affecting the country rocks and the ejecta ring), and eventually the crater may have become filled to a high level (Fig. 12c). During this phase, bedded pyroclastic deposits now represented by the disturbed bedded group were formed (infill 1), as well as debris avalanches, many sedimentary and pyroclastic megablocks, and invasive columns in the lower diatreme and within infill 1 (Fig. 12c). This first cycle of crater excavation and infill (Figs. 12b-12c) would have involved hundreds (or even thousands?) of phreatomagmatic explosions. At the end of this first cycle, we consider that the bottom part of infill 1 was already disturbed and crosscut by invasive columns (Fig, 12c). Then, a portion of infill 1 and associated invasive columns were both excavated back down to the unconformity during the second cycle of excavation and infilling (see below), forming truncated residual and invasive columns (Fig. 3).

At this stage, we consider that subterranean explosions, and the diatreme root zone, reached the Moenkopi Formation (Fig. 12c). This is demonstrated by Moenkopi clasts found in the disturbed bedded group and the non-bedded group.

\section{Second cycle of excavation and infilling}

A second cycle of crater excavation and infilling then followed (Figs. 12d, 12e). During this step, strong activity excavated some of the pyroclastic deposits of infill 1 and that material was partly transferred to the ejecta ring (Fig. 12d). This created a new crater floor that corresponds to the unconformity found all around Round Butte (Figs. 3 to 7 and S1.1 to S1.4). Excavation may have been strongest in the southwest part of the massif, leading to the development of a series of normal faults in this area.

A calmer period allowed renewed filling of the crater, to form infill 2, corresponding to the undisturbed pyroclastic group (Fig. 12e). These deposits were formed by fallback, fallout, as well as from dilute PDCs. Much of these pyroclastic deposits may have been fed from vents in the SW portion of 
the diatreme, including from what is now the nTBh column on the south face (Fig. 3).

Since the undisturbed bedded group (infill 2) contains fewer lithic clasts than the disturbed bedded group (infill 1) we consider that explosions probably occurred within the diatreme infill and that crater walls were mostly stable during this period. Minor widening of the crater is needed to explain the bTBm facies, which forms thick beds and lenses of Moenaverich pyroclastic rocks. During this stage, the bottom part of infill 1 probably became homogenized to form at least some of the nonbedded pyroclastic deposits of the lower diatreme.

\section{Post-eruptive events}

After the end of the eruption, there would have been a crater left, as is typical of maar volcanoes (White and Ross 2011). This crater would likely have become filled by post-eruptive sediments, as seen in less deeply eroded volcanoes of the HBVF further north, such as Teshim maar (White 1991). Finally, erosion removed the post-eruptive crater infill, some of the upper diatreme (infill 2), and the surrounding Colorado Plateau sedimentary rocks (Bidahochi Formation, Moenave Formation, and the top of the Owl Rock Member), to form the current massif (Fig. 12f).

\section{The upper/lower transition zone at Round Butte}

Generalized models of maar-diatreme volcanoes draw the contact between the upper diatreme and the lower diatreme as a sharp subhorizontal surface (White 1991; White and Ross 2011), or a concave surface (Lorenz 1986, 2003). Above the contact, pyroclastic deposits of the upper diatreme are bedded (although crossed by some non-bedded zones), and below the contact, deposits of the lower diatreme are non-bedded. The fact that the pyroclastic rocks below the unconformity at Round Butte also contain some bedding suggests a progressive, rather than abrupt, upper/lower transition between bedded and non-bedded rocks. The undisturbed bedded group, above the unconformity, formed during the second stage of crater infilling. Rocks below the unconformity include two types of columns: the invasive ones, formed by debris jets, and the residual ones, consisting of moderately to highly disturbed bedded pyroclastic rocks, emplaced during the first stage crater infilling. Bedding remnants within the residual columns only become apparent during close inspection of the base of the cliffs, or through the use of binoculars. The disturbed bedded material exposed below the unconformity does not resemble a classic lower, non-bedded diatreme. It is instead part of a transition zone toward the classic lower diatreme, i.e. at some depth below the current plain, all signs of bedding must disappear in the diatreme.

We therefore propose that the transition between the upper and lower diatreme is not an abrupt surface, but is a zone with a thickness of tens of metres at Round Butte, and perhaps hundreds of metres in larger diatremes. The transition zone is composed of a mixture of non-bedded and disturbed bedded deposits (Figs. 12f). At Round Butte, the upper contact of this transition zone corresponds to the unconformity formed by the second excavation phase. The lower contact of the transition zone is not exposed.

\section{Conclusion}

Round Butte is a small but complex Miocene diatreme, exposed $190 \mathrm{~m}$ below the preeruptive surface. Current outcrop includes bedded pyroclastic rocks (undisturbed and disturbed), non-bedded pyroclastic rocks, sedimentary and pyroclastic megablocks, and debris avalanche deposits. Detailed mapping of the cliffs allowed us to highlight relations between the different groups of facies in order to understand their emplacement dynamics and the evolution of the diatreme. Round Butte is a key site to understand:

1. how the cycles of crater excavation and infilling work;

2. the formation of non-bedded pyroclastic rocks that compose the lower diatreme;

3. the nature and significance of the transition between the upper and the lower diatreme. 
Two main cycles of crater excavation and infilling are responsible for the current architecture of the Round Butte diatreme. During the first cycle, country rocks were excavated to the deepest crater floor, as a result of an explosive phase. Then the crater was filled by pyroclastic deposits (mapped as the disturbed bedded pyroclastic group), megablocks and undifferentiated DADs, which became part of the diatreme (infill 1). Explosions created debris jets, which left behind invasive columns cross-cutting the disturbed pyroclastic beds. It should be noted that crater excavation and infilling occurred partly simultaneously, i.e. initially excavation was stronger than deposition, and then deposition became stronger, completing the first cycle. During the second cycle, infill 1 was partly excavated, forming the major unconformity seen at Round Butte, and this new crater was partly filled again by pyroclastic deposits (mapped as the undisturbed bedded group) which became the new upper diatreme (infill 2). Because phreatomagmatic explosions in maar-diatreme systems are thought to be relatively small (Valentine et al. 2014), excavating a large portion of the diatreme to temporarily leave a relatively deep crater, like happened twice at Round Butte, only seems possible for a small maar-diatreme volcano, or during the early stage of formation of a large one. For large mature diatremes, excavating the diatreme to depths over one kilometer seems very unlikely, especially in soft country rocks (Delpit et al. 2014).

At Round Butte, the bedded and nonbedded pyroclastic rocks in the diatreme formed simultaneously. We can therefore use the strong evidence for phreatomagmatism in the bedded pyroclastic rocks to interpret the origin of the non-bedded ones. Specifically, the disturbed bedded pyroclastic group and the non-bedded pyroclastic group are closely spatially associated and show similarities in componentry and grain size. Specific units within these groups display sub-vertical contacts and form column-like units (the residual and invasive columns, respectively). The disturbed bedded pyroclastic rocks are variably disturbed, and this is thought to be mostly due to injection of invasive columns as a result of explosion-related debris jets. Subsidence and liquefaction played lesser roles in the bedding disturbance. Over time, bedding would have completely disappeared at the bottom of infill 1. The lower non-bedded diatreme, therefore, results from progressive homogenization of bedded pyroclastic rocks mainly by injection of debris jets (Bélanger and Ross 2018).

Existing maar-diatreme models have two zones, the upper and the lower diatreme, separated by a sharp surface. We propose that a transition zone between the upper and lower diatreme, with a thickness in the metres to hundreds of metres range, should instead be included in maar-diatreme models (Fig. 13). This transition zone is another key to understand the formation of the lower diatreme. In volcanoes where the upper and lower diatreme are connected by this transition zone, it appears difficult to explain the formation of the upper and lower diatreme with completely different processes or eruption styles.

\section{Acknowledgments}

James D.L. White did the early work on Round Butte, introduced Pierre-Simon Ross to this fascinating volcano and read a draft of the manuscript. Pier Paolo Comida helped us in the field. We thank the Morris family for allowing us to work at Round Butte. Any persons wishing to conduct geological investigations on the Navajo Nation must first apply for, and receive, a permit from the Navajo Nation Minerals Department, P.O. Box 1910, Window Rock, Arizona 86515, USA, telephone 1-928-8716587. We thank Alison H. Graettinger and an anonymous reviewer for their constructive reviews, and editor Jacopo Taddeucci for his suggestions.

\section{References}

Austin-Erickson A, Ort MH, Carrasco-Núñez G (2011) Rhyolitic phreatomagmatism explored: Tepexitl tuff ring (Eastern Mexican Volcanic Belt). J Volcanol Geotherm Res 201:325-341 
Bélanger C, Ross P-S (2018) Origin of nonbedded pyroclastic rocks in the Cathedral Cliff diatreme, Navajo volcanic field, New Mexico. Bull Volcanol 80: article 61

Billingsley GH, Block D, Hiza-Redsteer M (2013) Geologic map of the Winslow $30^{\prime} \times 60^{\prime}$ quadrangle, Coconino and Navajo counties, northern Arizona. US Geological Survey Scientific Investigations, Map 3247, scale 1:50 000

Clement CR (1982) A comparative geological study of some major kimberlite pipes in the Northern Cape and Orange Free State. PhD thesis, University of Cape Town

Delpit S, Ross P-S, Hearn BC (2014) Deep-bedded ultramafic diatremes in the Missouri River Breaks volcanic field, Montana, USA: $1 \mathrm{~km}$ of syn-eruptive subsidence. Bull Volcanol 76:1-22

Fisher RV, Schmincke H-U (1984) Pyroclastic rocks. Springer, Berlin

Furnes H (1975) Experimental palagonitization of basaltic glasses of varied composition. Contrib Min Petrol 50:105-113

Gernon TM, Gilbertson MA, Sparks RSJ, Field M (2008) Gas-fluidisation in an experimental tapered bed: insights into processes in diverging volcanic conduits. J Volcanol Geotherm Res 174:4956

Gernon T, Upton B, Hincks T (2013) Eruptive history of an alkali basaltic diatreme from Elie Ness, Fife, Scotland. Bull Volcanol 75:1-20

Gilbert H, Velasco AA, Zandt G (2007) Preservation of Proterozoic terrane boundaries within the Colorado Plateau and implications for its tectonic evolution. Earth Planet Sci Lett 258:237-248

Graettinger A (2018) Trends in maar crater size and shape using the global Maar Volcano Location and Shape (MaarVLS) database. J Volcanol Geotherm Res 357:1-13

Graettinger AH, Valentine GA, Sonder I, Ross P-S, White JDL (2015) Facies distribution of ejecta in analog tephra rings from experiments with single and multiple subsurface explosions. Bull Volcanol 77:1-12

Hack JT (1942) Sedimentation and volcanism in the Hopi Buttes, Arizona. Geol Soc Am Bull 53:335372

Hart RJ, Ward JJ, Bills DJ, Flynn ME (2002) Generalized hydrogeology and ground-water budget for the $\mathrm{C}$ aquifer, Little Colorado River Basin and parts of the Verde and Salt River Basins, Arizona and New Mexico. US Geological Survey Water-Resources Investigations Report: 02-4026, 54 $\mathrm{p}$

Hooten JA (1999) Phreatomagmatic diatremes of the western Hopi Buttes volcanic field, Navajo Nation, Arizona. Msc thesis, University of Northern Arizona

Hooten J, Ort M (2002) Peperite as a record of early-stage phreatomagmatic fragmentation processes: an example from the Hopi Buttes volcanic field, Navajo Nation, Arizona, USA. J Volcanol Geotherm Res 114:95-106

Houghton B, Wilson C (1989) A vesicularity index for pyroclastic deposits. Bull volcanol 51:451-462

Kienle J, Kyle PR, Self S, Motyka RJ, Lorenz V (1980) Ukinrek Maars, Alaska, I. April 1977 eruption sequence, petrology and tectonic setting. J Volcanol Geotherm Res 7:11-37

Kurszlaukis S, Büttner R, Zimanowski B, Lorenz V (1998) On the first experimental phreatomagmatic explosion of a kimberlite melt. J Volcanol Geotherm Res 80:323-326 
Kurszlaukis S, Mahotkin I, Rotman A, Kolesnikov G, Makovchuk I (2009) Syn-and post-eruptive volcanic processes in the Yubileinaya kimberlite pipe, Yakutia, Russia, and implications for the emplacement of South African-style kimberlite pipes. Lithos 112:579-591

Le Corvec N, Muirhead JD, White JDL (2018) Shallow magma diversions during explosive diatremeforming eruptions. Nature Commun 9:1459-1459

Lefebvre NS (2013) Volcanology of maar-diatreme volcanic vent complexes, Hopi Buttes Volcanic Field, Navajo Nation, Arizona, USA. PhD thesis, University of Otago

Lefebvre N, White JDL, Kjarsgaard B (2013) Unbedded diatreme deposits reveal maar-diatreme-forming eruptive processes: Standing Rocks West, Hopi Buttes, Navajo Nation, USA. Bull Volcanol $75: 1-17$

Lefebvre NS, White JDL, Kjarsgaard BA (2016) Arrested diatreme development: Standing Rocks East, Hopi Buttes, Navajo Nation, USA. J Volcanol Geotherm Res 310:186-208

Lorenz V (1986) On the growth of maars and diatremes and its relevance to the formation of tuff rings. Bull Volcanol 48:265-274

Lorenz V (2003) Maar-diatreme volcanoes, their formation, and their setting in hard-rock or soft-rock environments. Geolines 15:72-83

Lorenz V (2007) Syn-and posteruptive hazards of maar-diatreme volcanoes. J Volcanol Geotherm Res 159:285-312

Lorenz V, Kurszlaukis S (2007) Root zone processes in the phreatomagmatic pipe emplacement model and consequences for the evolution of maar-diatreme volcanoes. J Volcanol Geotherm Res $159: 4-32$

Moore J (1967) Base surge in recent volcanic eruptions. Bull Volcanol 30:337-363

Muirhead JD, Van Eaton AR, Re G, White JDL, Ort MH (2016) Monogenetic volcanoes fed by interconnected dikes and sills in the Hopi Buttes volcanic field, Navajo Nation, USA. Bull Volcanol 78:1-16

Ort MH, Carrasco-Núñez G (2009) Lateral vent migration during phreatomagmatic and magmatic eruptions at Tecuitlapa Maar, east-central Mexico. J Volcanol Geotherm Res 181:67-77

Ort MH, Lefebvre NS, Neal CA, McConnell VS, Wohletz KH (2018) Linking the Ukinrek 1977 maareruption observations to the tephra deposits: New insights into maar depositional processes. J Volcanol Geotherm Res 360:36-60

Porritt L, Cas R, Crawford B (2008) In-vent column collapse as an alternative model for massive volcaniclastic kimberlite emplacement: an example from the Fox kimberlite, Ekati Diamond Mine, NWT, Canada. J Volcanol Geotherm Res 174:90-102

Re G, White JDL, Ort M (2015) Dikes, sills, and stress-regime evolution during emplacement of the Jagged Rocks complex, Hopi Buttes Volcanic field, Navajo Nation, USA. J Volcanol Geotherm Res 295:65-79

Re G, White JDL, Muirhead JD, Ort MH (2016) Subterranean fragmentation of magma during conduit initiation and evolution in the shallow plumbing system of the small-volume Jagged Rocks volcanoes (Hopi Buttes Volcanic Field, Arizona, USA). Bull Volcanol 78:1-20

Ripepe M, Delle Donne D, Harris A, Marchetti E, Ulivieri G (2008) Dynamics of Strombolian activity. In: Calvari S, Inguaggiato S, Puglisi G, Ripepe M, Rosi M (eds) The Stromboli Volcano: An Integrated Study of the 2002-2003 Eruption, American Geophysical Union, Geophysical Monograph 182:39-48 
Ross P-S, White JDL (2006) Debris jets in continental phreatomagmatic volcanoes: a field study of their subterranean deposits in the Coombs Hills vent complex, Antarctica. J Volcanol Geotherm Res 149:62-84

Ross P-S, White JDL, McClintock M (2008a) Geological evolution of the Coombs-Allan Hills area, Ferrar large igneous province, Antarctica: Debris avalanches, mafic pyroclastic density currents, phreatocauldrons. J Volcanol Geotherm Res 172:38-60

Ross P-S, White JDL, Zimanowski B, Büttner R (2008b) Multiphase flow above explosion sites in debris-filled volcanic vents: Insights from analogue experiments. J Volcanol Geotherm Res 178:104-112

Ross P-S, White JDL, Zimanowski B, Büttner R (2008c) Rapid injection of particles and gas into nonfluidized granular material, and some volcanological implications. Bull Volcanol 70:1151-1168

Ross P-S, White JDL, Valentine GA, Taddeucci J, Sonder I, Andrews RG (2013) Experimental birth of a maar-diatreme volcano. J Volcanol Geotherm Res 260:1-12

Ross P-S, Núñez GC, Hayman P (2017) Felsic maar-diatreme volcanoes: a review. Bull Volcanol 79:133

Self S, Kienle J, Huot J-P (1980) Ukinrek Maars, Alaska, II. Deposits and formation of the 1977 craters. J Volcanol Geotherm Res 7:39-65

Sohn YK (1996) Hydrovolcanic processes forming basaltic tuff rings and cones on Cheju Island, Korea. Geol Soc Am Bull 108:1199-1211

Sohn YK, Chough SK (1989) Depositional processes of the Suwolbong tuff ring, Cheju Island (Korea). Sedimentology 36:837-855

Stroncik NA, Schmincke H-U (2002) Palagonite-a review. Int J Earth Sci 91:680-697

Taddeucci J, Valentine GA, Sonder I, White JDL, Ross P-S, Scarlato P (2013) The effect of pre-existing craters on the initial development of explosive volcanic eruptions: An experimental investigation. Geophys Res Lett 40:507-510

Thomas APW (1888) Report on the Eruption of Tarawera and Rotomahana, New Zealand. Government Printer, Wellington, New Zealand

Valentine GA, White JDL (2012) Revised conceptual model for maar-diatremes: Subsurface processes, energetics, and eruptive products. Geology 40:1111-1114

Valentine GA, White JDL, Ross P-S, Amin J, Taddeucci J, Sonder I, Johnson PJ (2012) Experimental craters formed by single and multiple buried explosions and implications for volcanic craters with emphasis on maars. Geophys Res Lett 39:L20301

Valentine GA, Graettinger AH, Sonder I (2014) Explosion depths for phreatomagmatic eruptions. Geophys Res Lett 41:3045-3051

Valentine GA, Sottili G, Palladino DM, Taddeucci J (2015) Tephra ring interpretation in light of evolving maar-diatreme concepts: Stracciacappa maar (central Italy). J Volcanol Geotherm Res 308:1929

van Otterloo J, Ort MH, Cruden AR (2018) Unique occurrence of a folded in-vent dike: New insights on magma-water mixing. Geology 46:379-382

Vazquez JA (1998) Maar volcanism in the Wood Chop Mesa area, Hopi Buttes volcanic field, Navajo Nation, Arizona. Msc thesis, University of Northern Arizona 
Vazquez JA, Ort MH (2006) Facies variation of eruption units produced by the passage of single pyroclastic surge currents, Hopi Buttes volcanic field, USA. J Volcanol Geotherm Res 154:222236

White JDL (1989) Basic elements of maar-crater deposits in the Hopi Buttes volcanic field, northeastern Arizona, USA. J Geol 97:117-125

White JDL (1990) Depositional architecture of a maar-pitted playa: sedimentation in the Hopi Buttes volcanic field, northeastern Arizona, USA. Sediment Geol 67:55-84

White JDL (1991) Maar-diatreme phreatomagmatism at Hopi Buttes, Navajo Nation (Arizona), USA. Bull Volcanol 53:239-258

White JDL (1996) Impure coolants and interaction dynamics of phreatomagmatic eruptions. J Volcanol and Geotherm Res 74:155-170

White JDL, McClintock M (2001) Immense vent complex marks flood-basalt eruption in a wet, failed rift: Coombs Hills, Antarctica. Geology 29:935-938

White JDL, Houghton B (2006) Primary volcaniclastic rocks. Geology 34:677-680

White JDL, Ross P-S (2011) Maar-diatreme volcanoes: a review. J Volcanol Geotherm Res 201:1-29

White JDL, Houghton B (2015) Surtseyan and related phreatomagmatic eruptions. In: Sigurdsson H, Houghton B, McNutt SR, Rymer H, Stix J (eds) Encyclopedia of Volcanoes. Elsevier second edition 495-511

Williams H (1936) Pliocene volcanoes of the Navajo-Hopi country. Geol Soc Am Bull 47:111-172

Zimanowski B, Büttner R, Lorenz V, Häfele HG (1997) Fragmentation of basaltic melt in the course of explosive volcanism. J Geophys Res: Solid Earth 102:803-814 


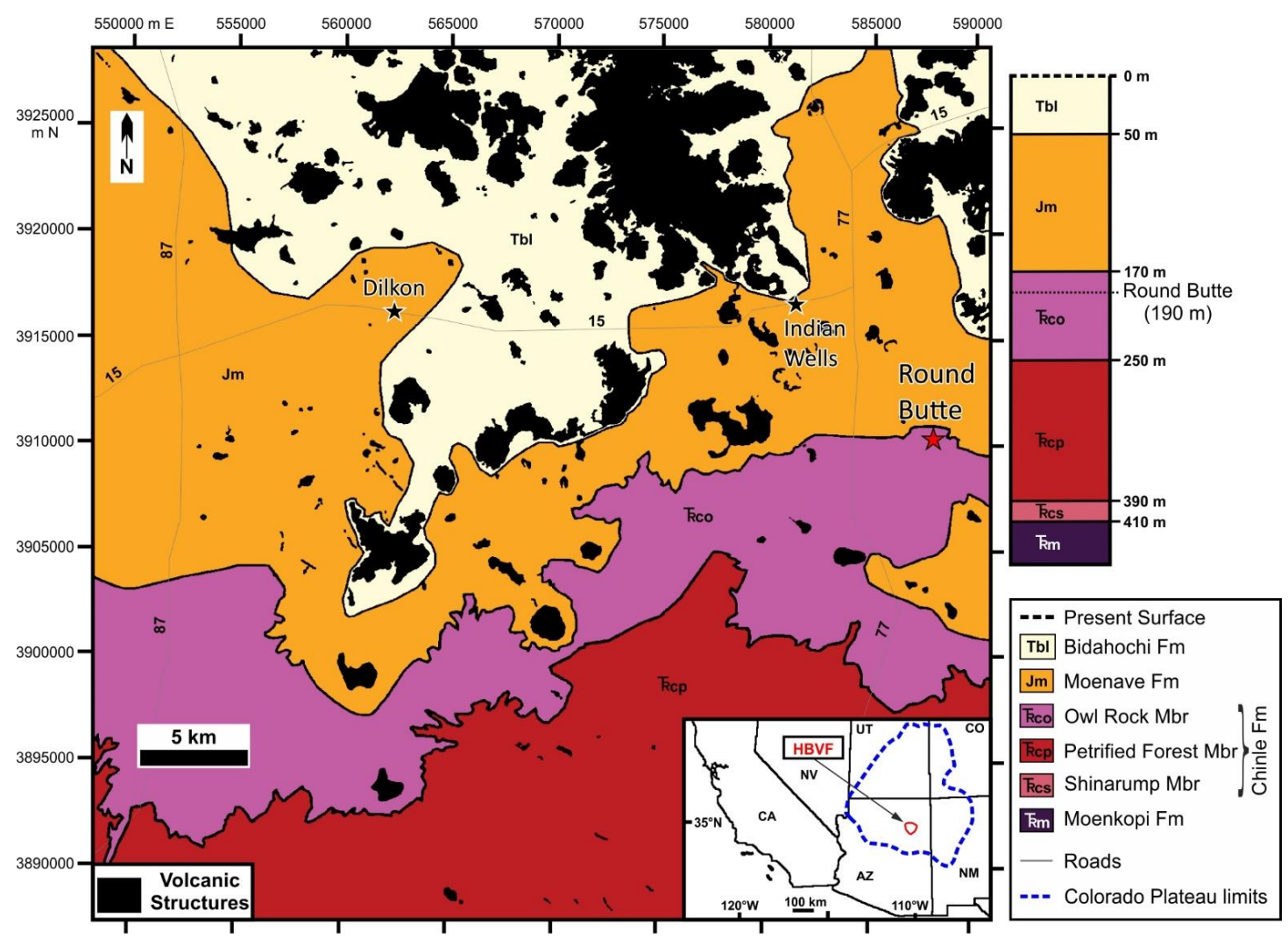

Fig. 1 Geological map showing a portion of the Hopi Buttes volcanic field (HBVF, black) and the sedimentary formations that crop out in the region. Grid is UTM WGS 84 zone 12S. Stratigraphic column illustrates the position of the base of the cliff at Round Butte relative to the pre-eruptive surface. Inset map locates the HBVF in the SW United States. Modified from Lefebvre (2013). 


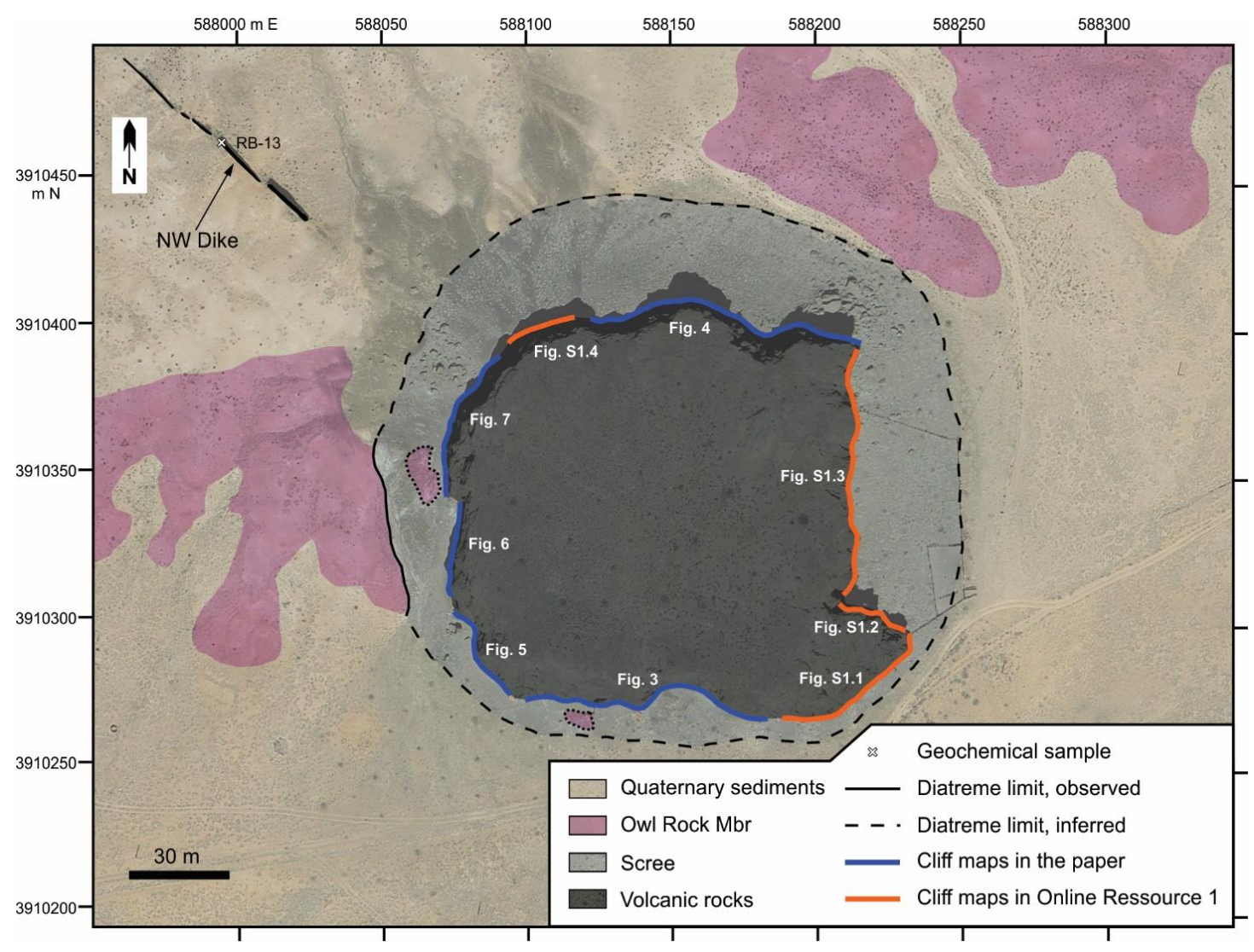

Fig. 2 Round Butte geological map displaying the igneous remnants (diatreme and NW dike) and the location of the different panoramic photographs used for drawing cliff maps. Grid is UTM WGS 84, zone $12 \mathrm{~S}$. 


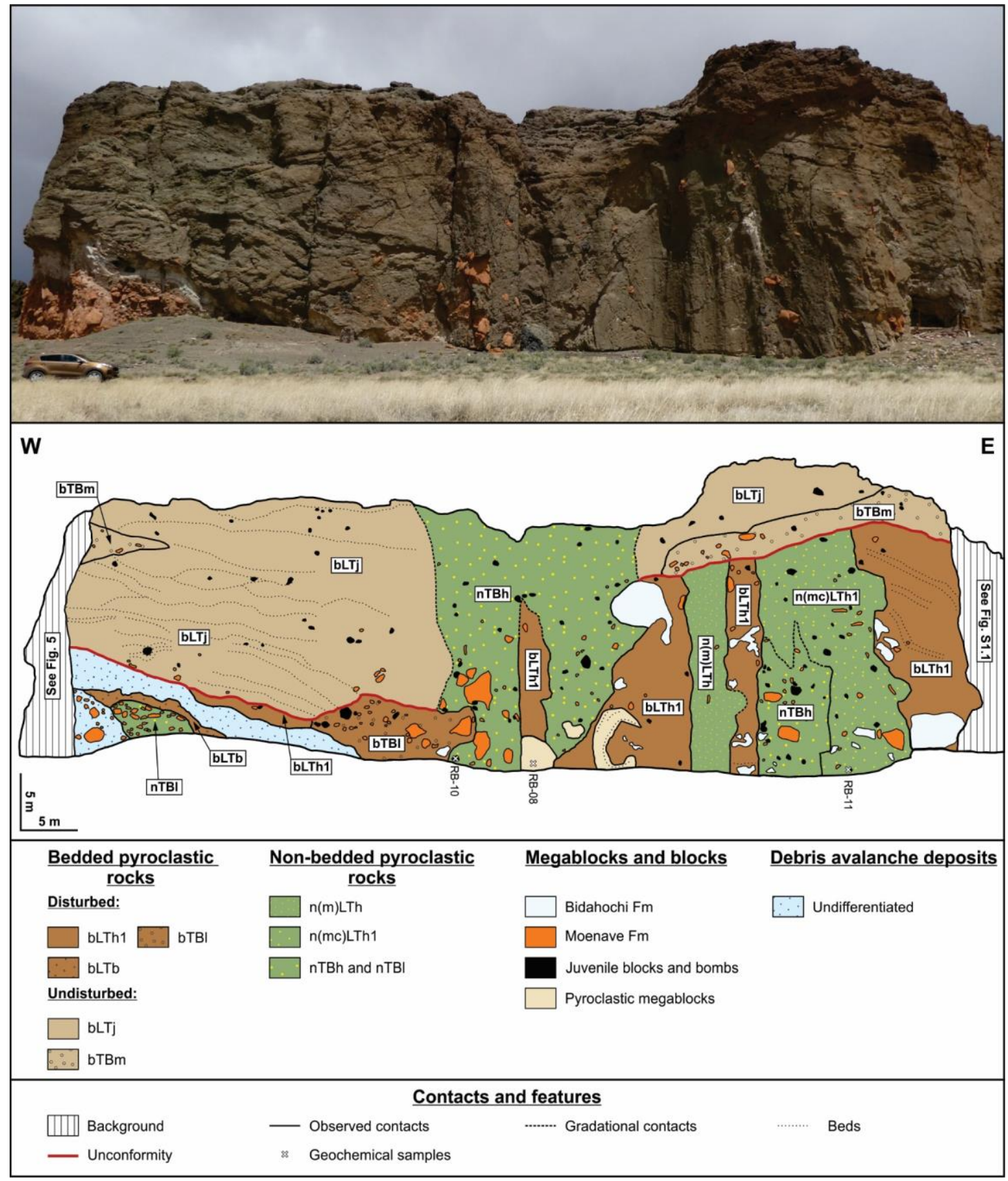

Fig. 3 Geological map of the cliffs in the south part of Round Butte (location in Fig. 2) displaying the three main facies groups. Note the truncated invasive columns (non-bedded pyroclastic rocks), the unconformity, the discordant contact (onlap) between the undisturbed and the disturbed bedded group just above the bTBl facies. For facies codes, see Tables 1 to 3. 


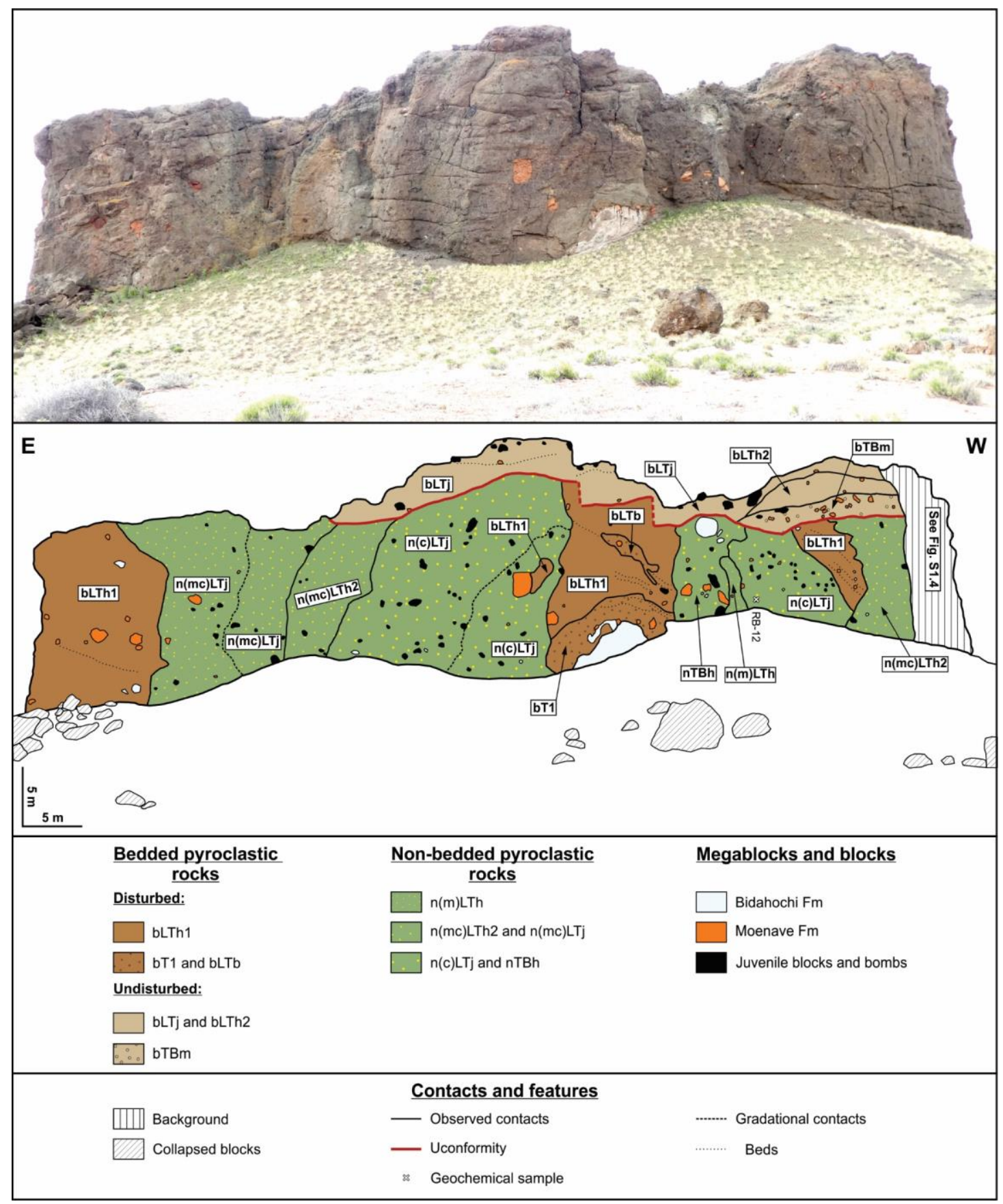

Fig. 4 Geological map of the cliffs in the north part of Round Butte (location in Fig. 2) displaying the three main facies groups. Note the truncated invasive columns and the unconformity. For facies codes, see Tables 1 to 3 . 


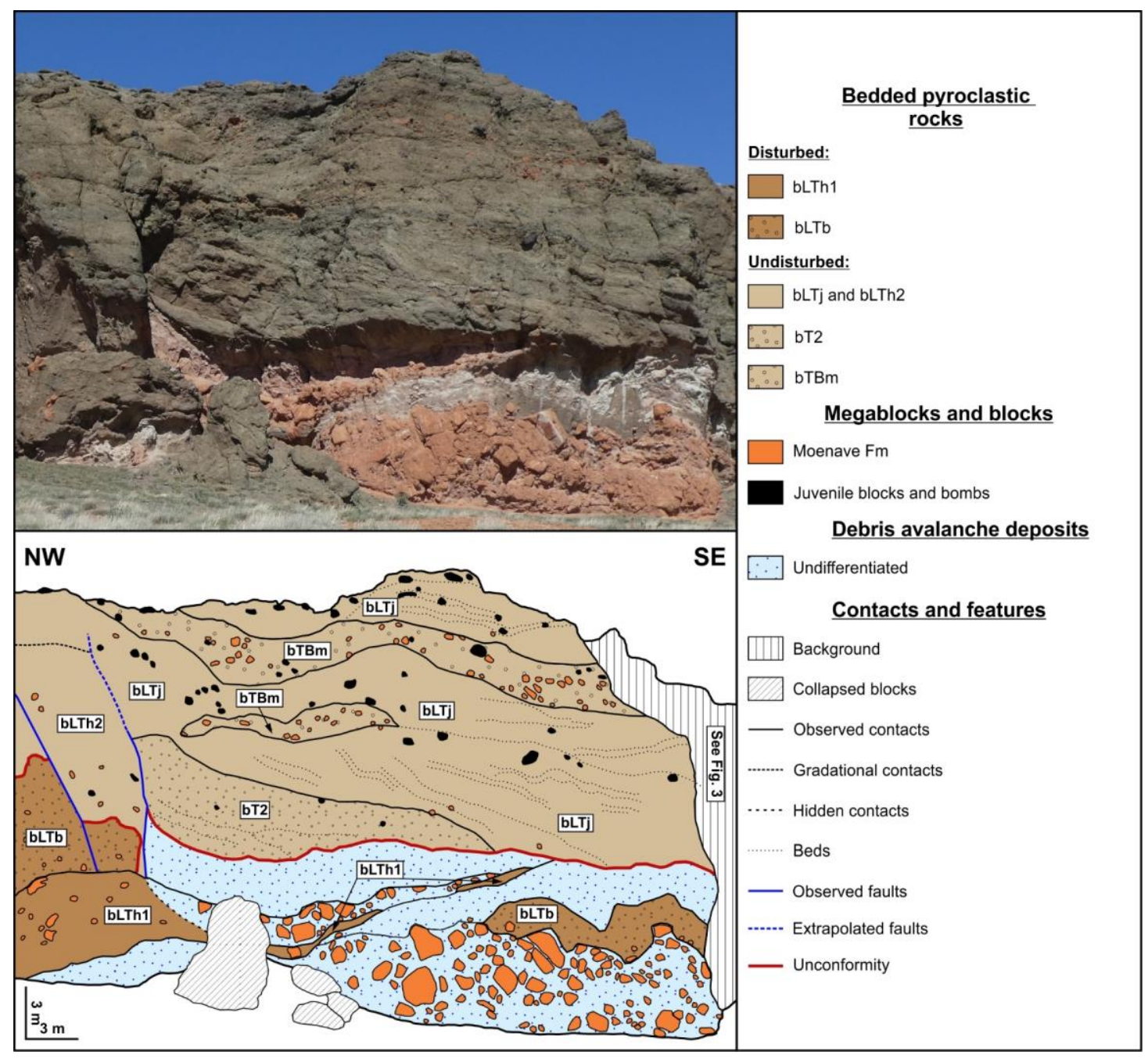

Fig. 5 Geological map of the cliffs in the southwest part of Round Butte (location in Fig. 2) displaying two main facies groups. For facies codes, see Tables 1 and 2. 


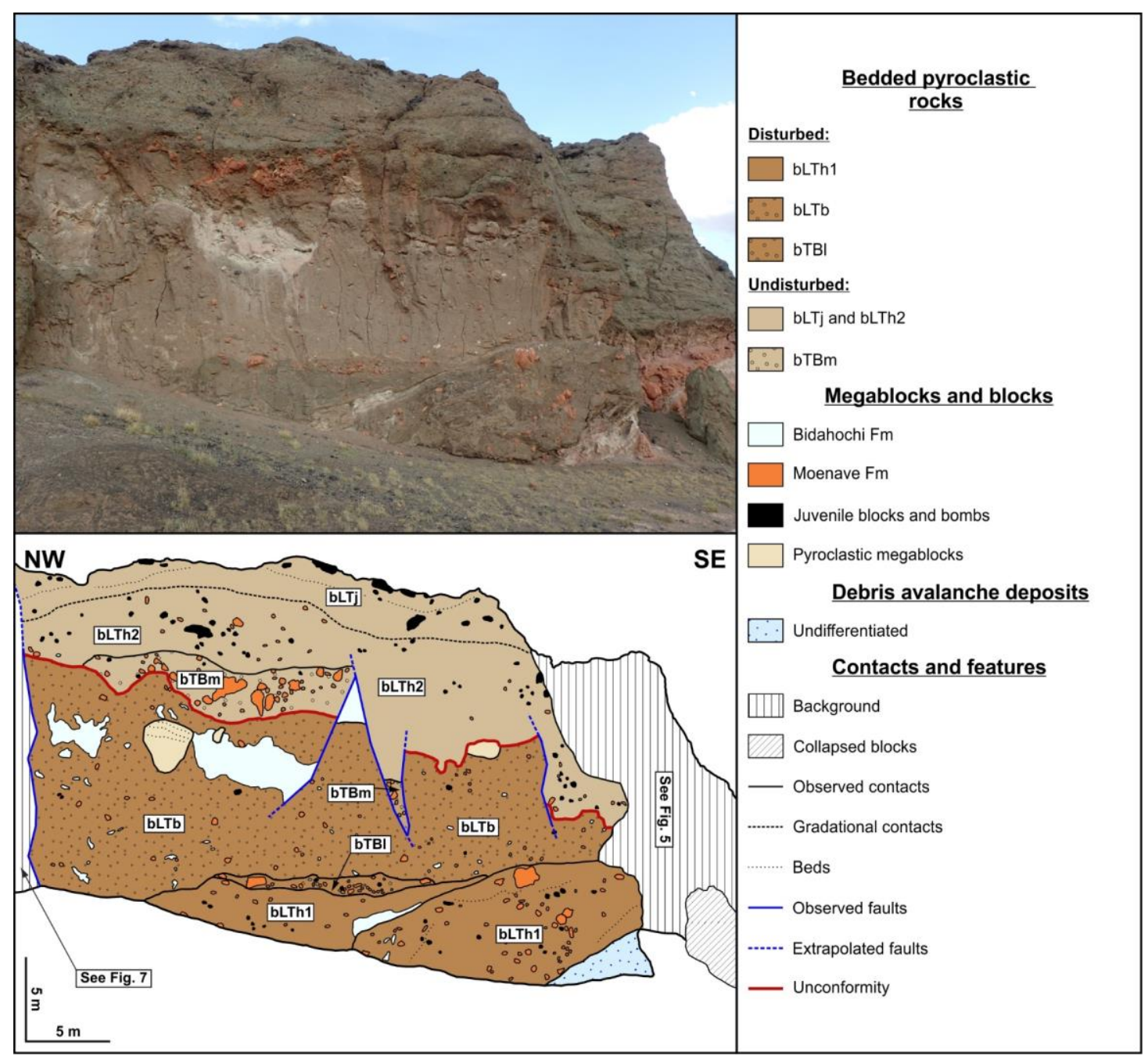

Fig. 6 Geological map of the cliffs in the west part of Round Butte (location in Fig. 2) displaying two main facies groups. Note the irregular and faulted unconformity. For facies codes, see Tables 1 and 2. 


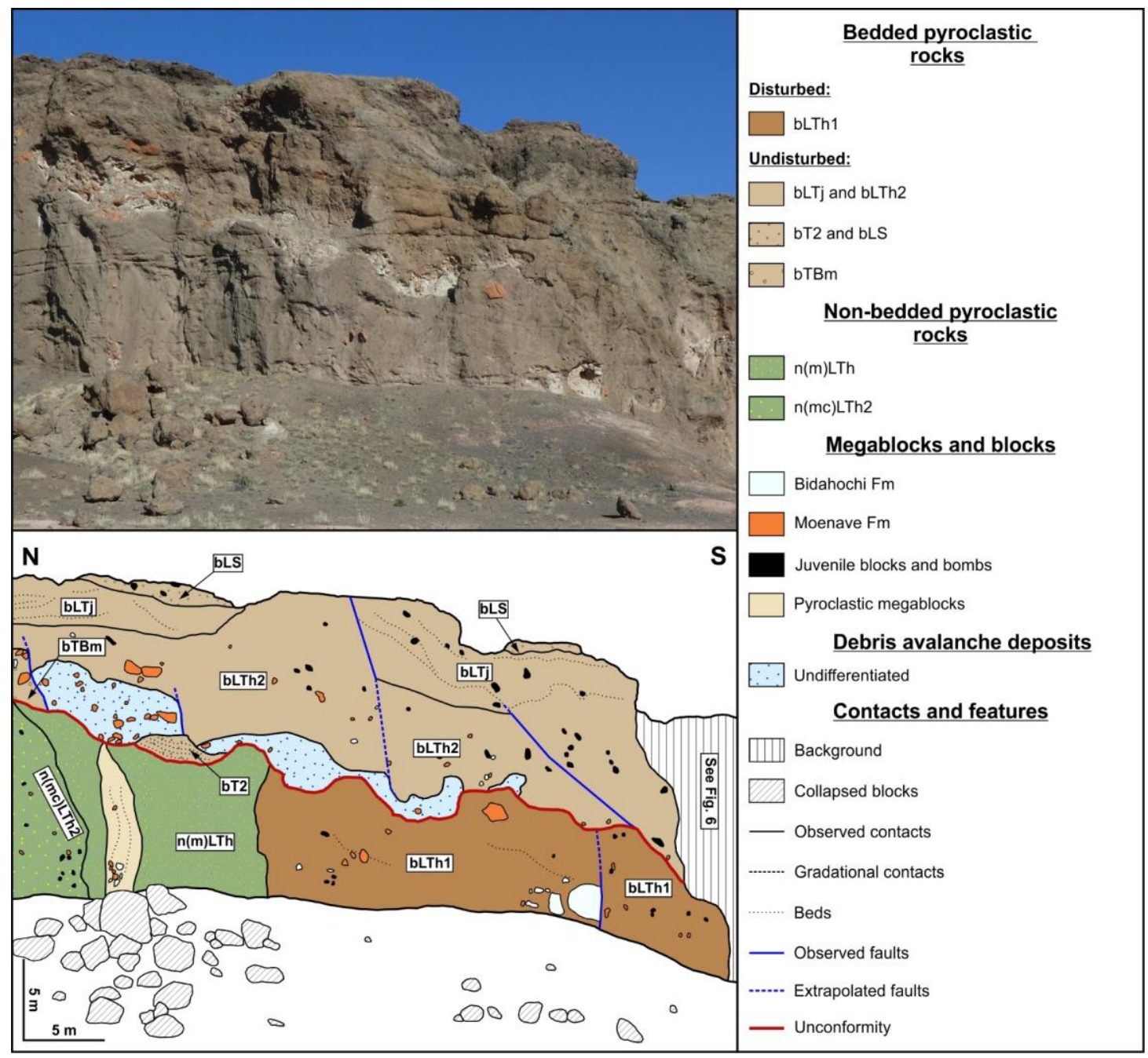

Fig. 7 Geological map of the cliffs in the west-northwest part of Round Butte (location in Fig. 2) displaying the three main facies groups. Note the truncated invasive columns, the irregular unconformity, and the minor faults. For facies codes, see Tables 1 to 3. 

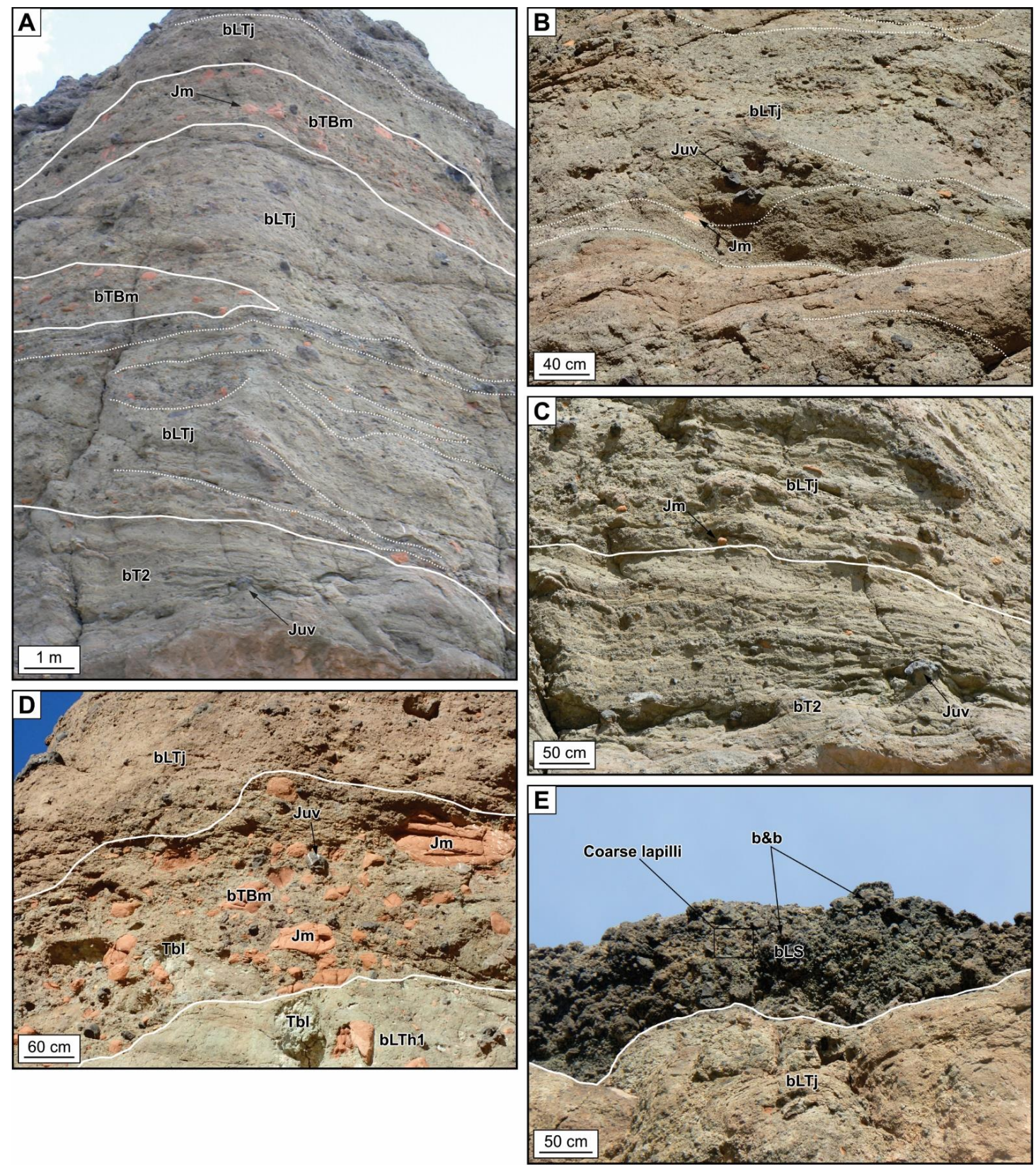

Fig 8 Photo plate of the principal facies of the undisturbed bedded pyroclastic rocks. A) General view of the thickest portion of the undisturbed bedded group in the southwest part of Round Butte diatreme, displaying organization of the bLTj, bT2 and bTBm facies. B) Close-up view of the diffusely bedded bLTj facies. C) Close up view of the thinly bedded bT2 facies, here overlain by bLTj. D) Close-up of a thick bed of bTBm facies displaying a high content of Moenave blocks. E) bLS facies mostly contains dark grey to black coarse lapilli. Abbreviations: Tbl=Bidahochi clasts, Jm=Moenave clasts, Juv=Juvenile clasts and $b \& b=b l o c k s$ and bombs; facies codes see Tables 1 and 2. 

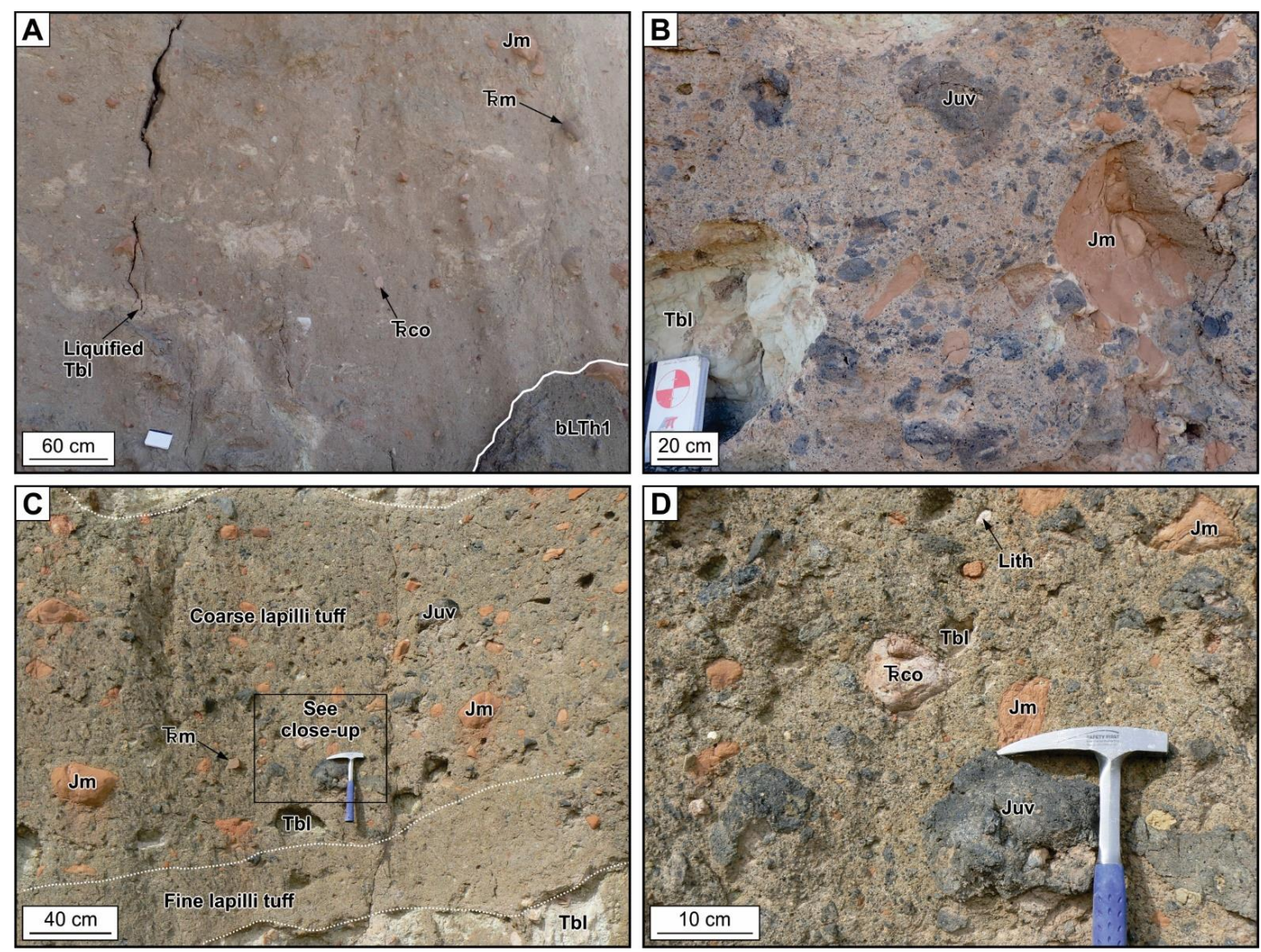

Fig. 9 Photo plate of the principal facies of the disturbed bedded pyroclastic rocks. A) Structureless thick bed ( $10 \mathrm{~m}$ thick) of the bLTb facies, displaying various lithic clasts including liquefied Bidahochi clasts, and a recycled tuff fragment. B) Lithic-rich bTB1 facies, with Moenave and Bidahochi clasts and some juvenile blocks. C) Main disturbed facies bLTh1, with sub-horizontal beds between to blocks of Bidahochi Formation. D) Close-up of bLTh1 facies with a great diversity of lithic clasts. Abbreviations: Tbl=Bidahochi clasts, Jm=Moenave clasts, Trco=Owl Rock clasts, Trm=Moenkopi clasts and Juv=Juvenile clasts; facies codes see Table 2. 

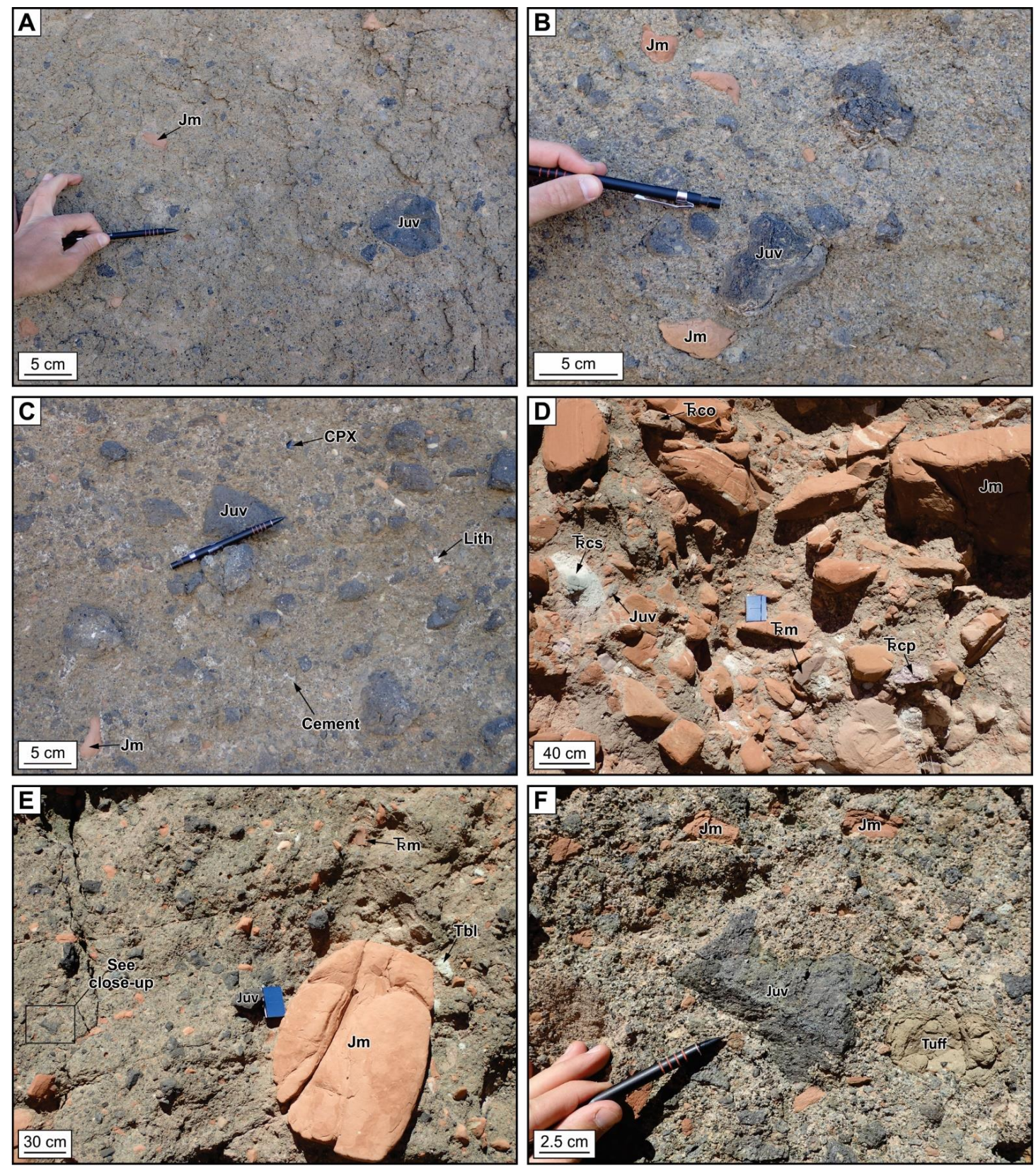

Fig. 10 Photo plate of the principal facies of the non-bedded pyroclastic group. A) n(m)LTh corresponds to the finer non-bedded facies. B) Close-up view of $n(m c) L T h 2 . C)$ The coarse facies $n(c) L T j$, rich in dark grey to black juvenile coarse lapilli. D) The coarser facies in the massif, nTBl, mainly composed of a great diversity of lithics principally represented by Moenave blocks. E) The coarse nTBh facies with a relatively high lithic content between juvenile clasts. F) Close-up of the nTBh facies. Abbreviations: Tbl=Bidahochi clasts, Jm=Moenave clasts, Trco=Owl Rock clasts, Trcp=Petrified Forest clasts, Trcs=Shinarump clasts, Trm=Moenkopi clasts, Juv=Juvenile clasts, Lith= undifferentiated lithic clasts and $\mathrm{CPX}=$ free clinopyroxene; facies codes see Table 3. 

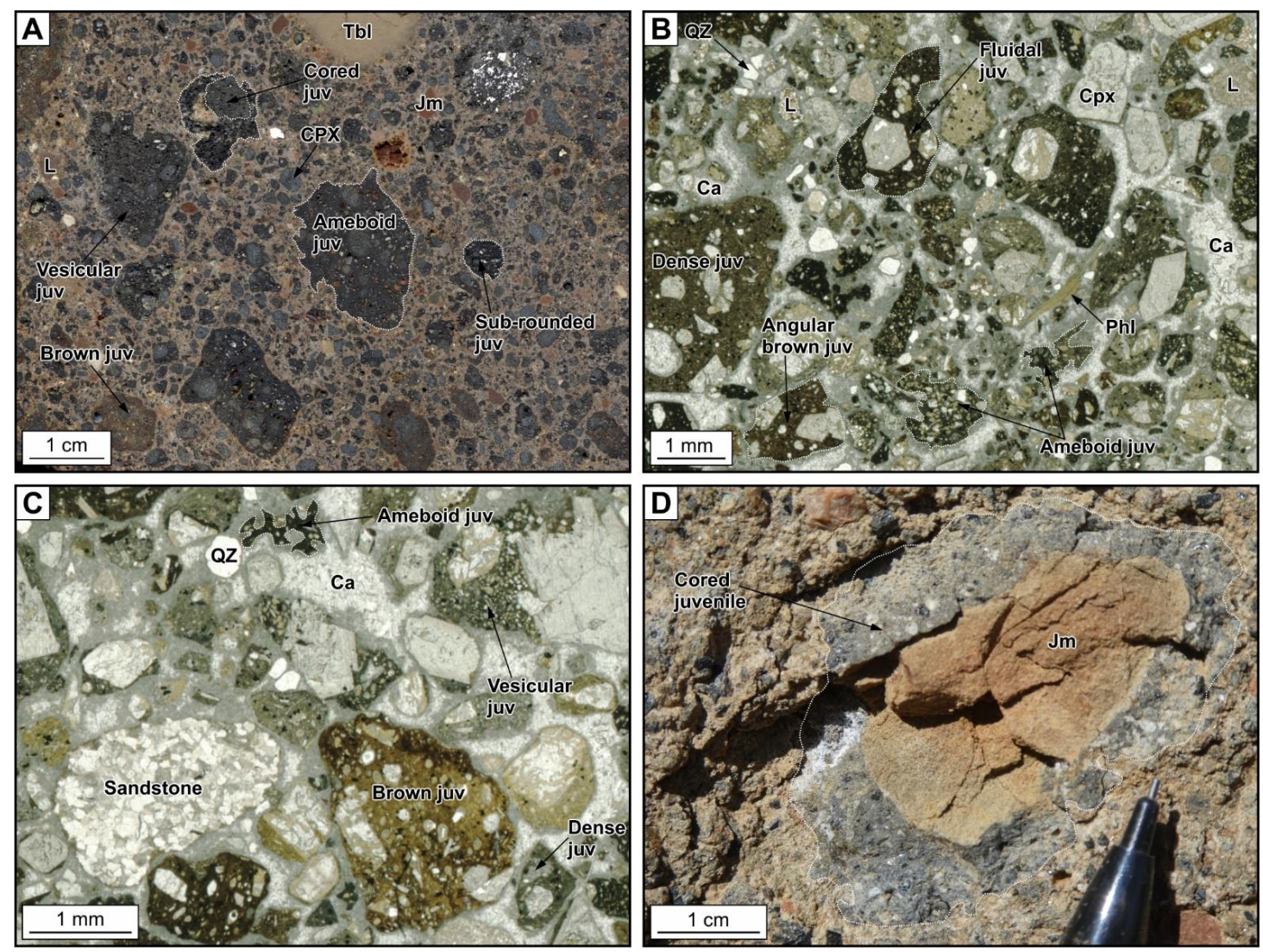

Fig. 11 Photo plate showing the diversity and the morphology of juvenile clasts. A) Slab of bLTh1 facies highlighting the diversity of lithics and the morphology (amoeboid to sub-rounded) of juvenile clasts (brown and grey). The cored juvenile fragment evidences recycling processes in the diatreme. B) and C) thin section scans of facies bLTh1, highlighting the variability of the morphology of juvenile clasts in thin section. D) Moenave cored bomb. Abbreviations: Tbl=Bidahochi clasts, Jm=Moenave clasts, Trm=Moenkopi clasts, Juv=Juvenile clasts, L=Lithic clasts, CPX=free clinopyroxene, $\mathrm{Phl}=$ pholgopite and $\mathrm{Ca}=\mathrm{Calcite}$ cement; facies codes see Tables 1 . 

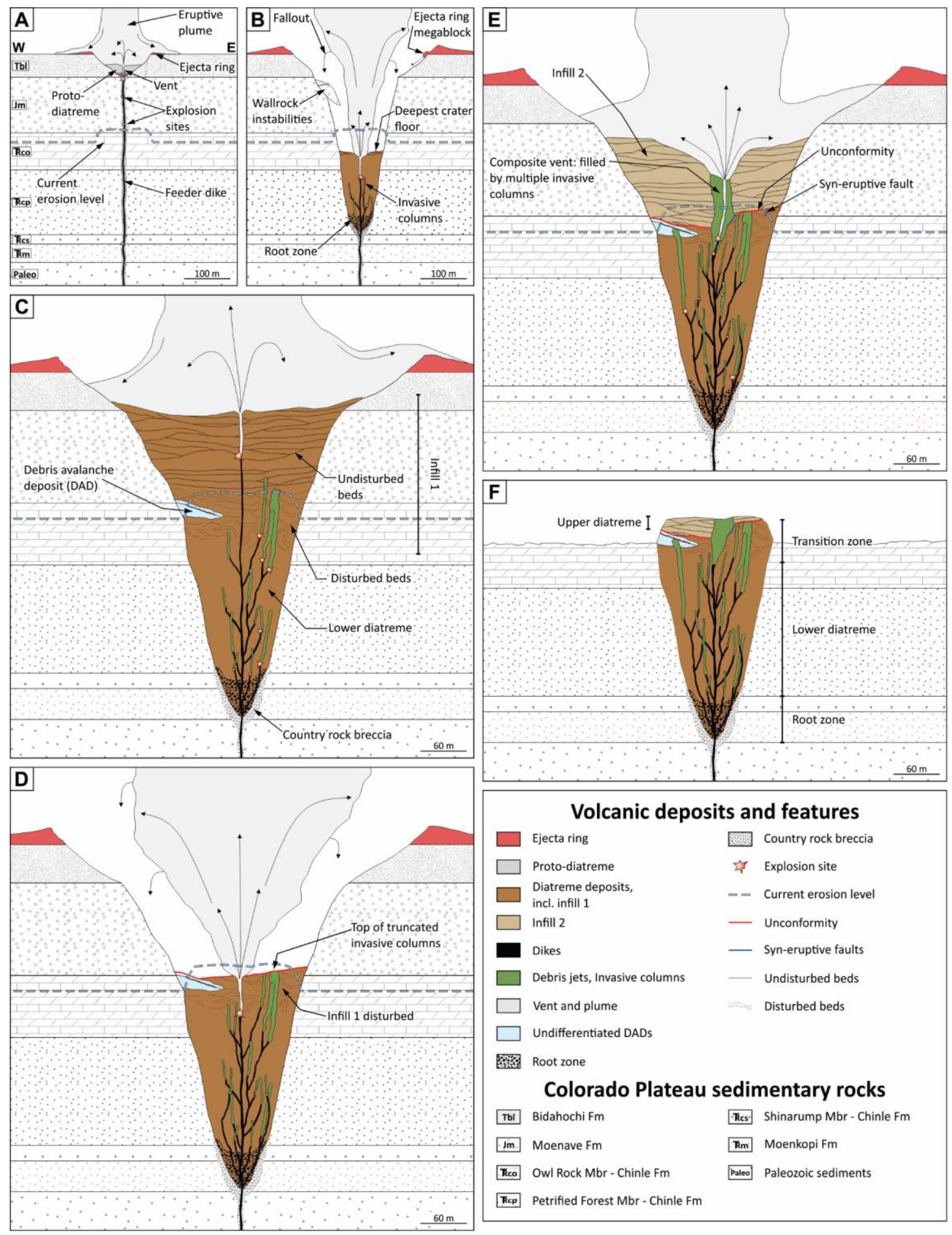

Fig. 12 The six-step Round Butte evolution model. A) Onset of activity when a basanite dike rises through sedimentary rocks and forms the first crater in the Bidahochi Formation. B) First major excavation phase with the formation of the deepest crater. C) First phase of crater infill, forming the infill 1. D) Infill 1 is excavated during the second major phase of excavation. E) Formation of infill 2 and end of eruptive activity. F) Current erosion level at Round Butte. Note that during each cycle, crater excavation and infilling occurred partly simultaneously, i.e. initially excavation was stronger than deposition, and then deposition became stronger. 


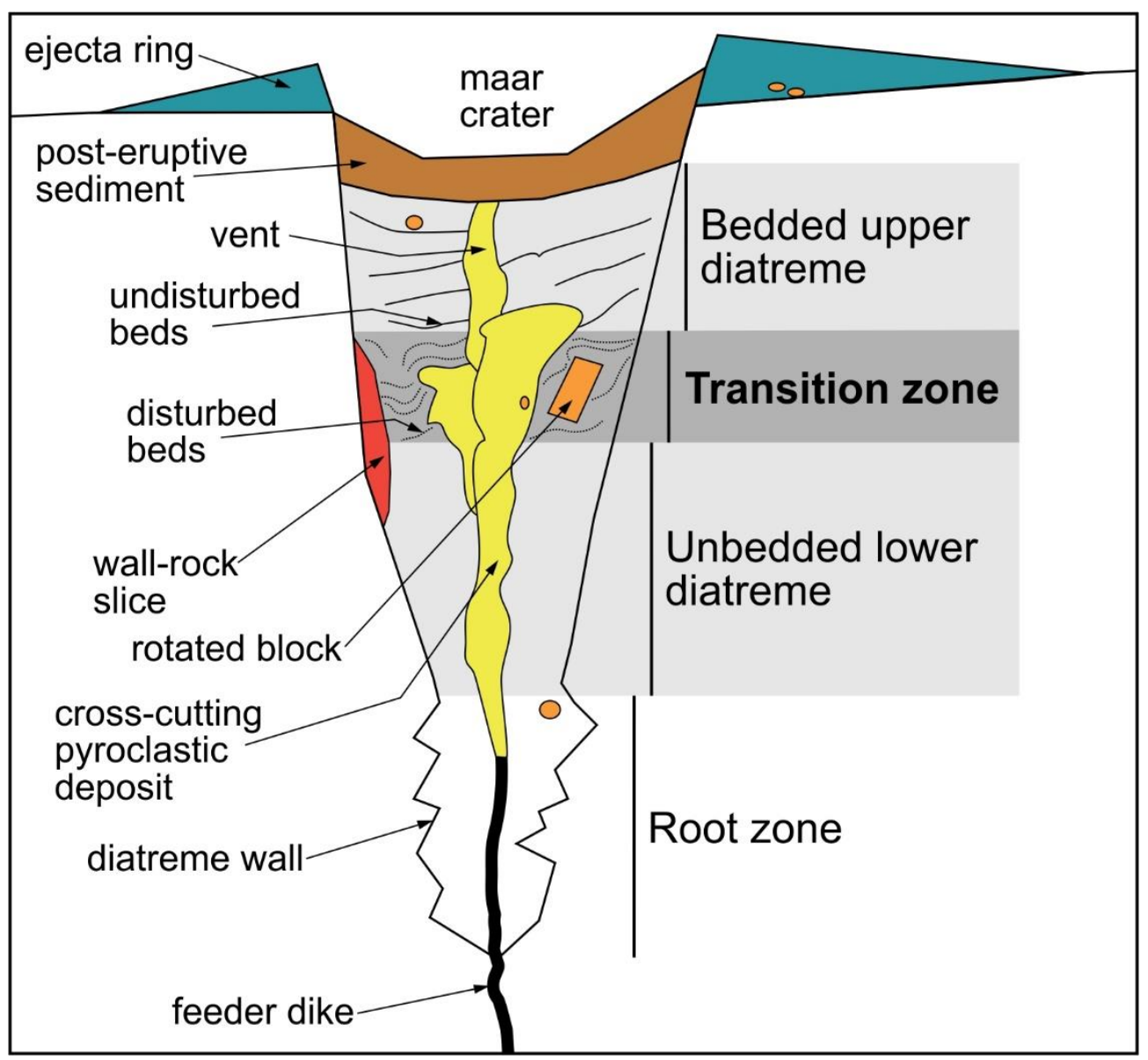

Fig. 13 General maar-diatreme cross-sectional sketch introducing the concept of a transition zone between the upper and lower diatreme. Modified from White and Ross (2011). 


\begin{tabular}{|c|c|c|c|c|c|c|c|c|}
\hline $\begin{array}{l}\text { Facies } \\
\text { code }\end{array}$ & Name & $\begin{array}{l}\text { Bed } \\
\text { thickness }\end{array}$ & $\begin{array}{l}\text { Blocks and } \\
\text { bombs }\end{array}$ & Lapilli & Ash & Cement & Comments & $\begin{array}{l}\text { Panoramas } \\
\text { (Fig. nb) }\end{array}$ \\
\hline bT2 & $\begin{array}{l}\text { Bedded tuff to fine } \\
\text { lapilli tuff, juvenile- } \\
\text { rich, with thin beds }\end{array}$ & $\mathrm{cm}$ to $\mathrm{dm}$ & $\begin{array}{l}\sim 0 \%, \\
\text { Juv }>\text { Lith } \\
(\mathrm{Jm})\end{array}$ & $\begin{array}{l}\text { Unknown } \\
\text { but }>10 \%\end{array}$ & $<90 \%$ & $?$ & $\begin{array}{l}\text { Thin beds with cross-bedding, dunes and some bomb } \\
\text { sags (Figs. } 8 \mathrm{a}, 8 \mathrm{c} \text { ). }\end{array}$ & 5,7 \\
\hline bLTj & $\begin{array}{l}\text { Bedded medium to } \\
\text { coarse lapilli tuff, } \\
\text { juvenile-rich }\end{array}$ & $\mathrm{dm}$ to $\mathrm{m}$ & $\begin{array}{l}<1 \% \\
\text { Juv }>>\text { Lith } \\
(\mathrm{Jm})\end{array}$ & $\begin{array}{l}\text { Unknown } \\
\text { but }>25 \%\end{array}$ & $<75 \%$ & $?$ & $\begin{array}{l}\text { Contacts between beds are sometimes difficult to see. } \\
\text { Bomb sags are locally observable. A few blocks of } \\
\text { Moenave Fm are present (Figs. } 8 \mathrm{a}, 8 \mathrm{~b} \text { ). }\end{array}$ & $\begin{array}{l}3,4,5,6,7 \\
\text { S1.1 to } S 1.4\end{array}$ \\
\hline bLTh2 & $\begin{array}{l}\text { Bedded medium to } \\
\text { coarse lapilli tuff, } \\
\text { heterolithic }\end{array}$ & $\mathrm{dm}$ to $\mathrm{m}$ & $\begin{array}{l}3-5 \% \\
\text { Juv }>\text { Lith } \\
(\mathrm{Jm}>\mathrm{Tbl})\end{array}$ & $\begin{array}{l}\text { Unknown } \\
\text { but }>25 \%\end{array}$ & $<75 \%$ & $?$ & $\begin{array}{l}\text { Very diffusely bedded. Beds are mostly metric with } \\
\text { gradational contacts and various amounts of lithics. }\end{array}$ & $\begin{array}{l}4,5,6,7 \\
\text { S1.1, S1.4 }\end{array}$ \\
\hline bTBm & $\begin{array}{l}\text { Bedded tuff breccia, } \\
\text { Moenave-rich }\end{array}$ & $\mathrm{m}$ & $\begin{array}{l}25-35 \% \\
\text { Lith }(\mathrm{Jm}>> \\
\text { Tbl) }>>\text { Juv }\end{array}$ & $?$ & $?$ & $?$ & $\begin{array}{l}\text { Structureless beds or lenses mainly composed of } \\
\text { Moenave Fm blocks and some juvenile blocks/bombs. } \\
\text { In some units, blocks of Bidahochi Fm are present (Fig. } \\
\text { 8d). }\end{array}$ & $\begin{array}{l}3,4,5,6,7 \\
\text { S1.1, S1.4 }\end{array}$ \\
\hline bLS & $\begin{array}{l}\text { Bedded lapillistone, } \\
\text { juvenile-rich }\end{array}$ & $\mathrm{m}$ & $\begin{array}{l}<2 \% \\
\text { Juv only }\end{array}$ & $>75 \%$ & $<25 \%$ & $?$ & $\begin{array}{l}\text { The best sorted facies in the massif, composed of coarse } \\
\text { dark grey to black juvenile lapilli and blocks/bombs } \\
\text { (Fig. 8e). Probably rich in scoria. }\end{array}$ & 7 \\
\hline
\end{tabular}

*Due to inaccessibility, the description of these units was done from a distance using binoculars $J u v=$ Juvenile clasts, Lith = Lithic clasts, Jm = Moenave Fm clasts, Tbl=Bidahochi Fm clasts 
Table 2 Characteristics of disturbed bedded pyroclastic rocks

\begin{tabular}{|c|c|c|c|c|c|c|c|c|}
\hline $\begin{array}{l}\text { Facies } \\
\text { code }\end{array}$ & Name & $\begin{array}{l}\text { Bed } \\
\text { thickness }\end{array}$ & $\begin{array}{l}\text { Blocks and } \\
\text { bombs }\end{array}$ & Lapilli & Ash & Cement & Comments & $\begin{array}{l}\text { Panoramas } \\
\text { (Fig. nb) }\end{array}$ \\
\hline bT1 & $\begin{array}{l}\text { Bedded tuff to fine } \\
\text { lapilli tuff, juvenile- } \\
\text { rich, with thin beds }\end{array}$ & $\mathrm{cm}$ to $\mathrm{dm}$ & $\begin{array}{l}<1 \%, \\
\text { Lith }(\mathrm{Jm})>> \\
\text { Juv }\end{array}$ & $\begin{array}{l}20-30 \% \\
\text { Juv }>>\text { Lith } \\
(\mathrm{Jm}>\mathrm{Tbl})\end{array}$ & $\begin{array}{l}68-78 \%, \\
\text { mostly } \\
\text { fine ash }\end{array}$ & $\begin{array}{l}0-1 \%, \\
\text { scattered }\end{array}$ & $\begin{array}{l}\text { Thinly bedded units mostly composed of ash } \\
\text { and fine lapilli. Juvenile bombs are more } \\
\text { abundant than blocks. Brown juvenile clasts } \\
\text { are difficult to distinguish from the matrix }\end{array}$ & $4, \mathrm{~S} 1.1$ \\
\hline bLTb & $\begin{array}{l}\text { Bedded fine to medium } \\
\text { lapilli tuff, brown }\end{array}$ & $\begin{array}{l}\mathrm{dm} \text { to } \sim 10 \\
\mathrm{~m}\end{array}$ & $\begin{array}{l}0-3 \% \\
\text { Lith }(\mathrm{Jm}>\mathrm{Tbl} \\
>\mathrm{TRm}> \\
\text { TRc) }>>\text { Juv }\end{array}$ & $\begin{array}{l}15-40 \% \\
\text { Juv } \geq \text { Lith }(\mathrm{Jm} \\
\geq \mathrm{Tbl}>\mathrm{TRm} \\
>\text { TRc })\end{array}$ & $\begin{array}{l}55-85 \% \\
\text { mostly } \\
\text { fine ash }\end{array}$ & $\begin{array}{l}0-2 \% \\
\text { scattered }\end{array}$ & $\begin{array}{l}\text { Structureless, mostly composed of ash and } \\
\text { fine to medium lapilli (Fig. 9a). Brown } \\
\text { juvenile clasts are difficult to distinguish } \\
\text { from the matrix. Presence of block-sized } \\
\text { fragments of recycled tuff. }\end{array}$ & $3,4,5,6$ \\
\hline bLTh1 & $\begin{array}{l}\text { Bedded medium to } \\
\text { coarse lapilli tuff, } \\
\text { heterolithic }\end{array}$ & $\begin{array}{l}\mathrm{m} \text { to tens } \\
\text { of } \mathrm{m}\end{array}$ & $\begin{array}{l}0-30 \% \\
\text { Juv } \geq \text { Lith }(\mathrm{Jm} \\
>\text { Tbl }>\text { TRm, } \\
\text { TRc) }\end{array}$ & $\begin{array}{l}20-70 \% \\
\text { Juv }>\text { Lith }(\mathrm{Jm} \\
>\text { Tbl }>\text { TRm, } \\
\text { TRc) }\end{array}$ & $\begin{array}{l}20-80 \%, \\
\text { fine to } \\
\text { coarse ash } \\
\text { varying } \\
\text { with beds }\end{array}$ & $\begin{array}{l}0-15 \% \\
\text { scattered } \\
\text { to patchy }\end{array}$ & $\begin{array}{l}\text { Highly heterogeneous facies, mostly lapilli } \\
\text { tuff, but local occurrence of coarse tuff and } \\
\text { tuff breccia beds (Figs. 9c, 9d). Most of the } \\
\text { units are richer in juvenile bombs than } \\
\text { blocks. Brown juvenile clasts mostly in trace } \\
\text { amounts. Presence of lapilli-sized fragments } \\
\text { of recycled tuff. }\end{array}$ & $\begin{array}{l}3,4,5,6,7, \\
\text { S1.1 to } S 1.4\end{array}$ \\
\hline $\mathrm{b}(\mathrm{c}) \mathrm{LTj}$ & $\begin{array}{l}\text { Bedded coarse lapilli } \\
\text { tuff, juvenile-rich }\end{array}$ & $\mathrm{m}$ & $\begin{array}{l}10 \% \\
\text { Juv }>>\text { Lith } \\
(\mathrm{Jm}>\mathrm{Tbl})\end{array}$ & $\begin{array}{l}60-70 \% \\
\text { Juv }>\text { Lith } \\
(\mathrm{Jm}>\mathrm{Tbl})\end{array}$ & $\begin{array}{l}19-29 \%, \\
\text { altered, } \\
\text { mostly } \\
\text { coarse ash }\end{array}$ & $\begin{array}{l}1 \%, \\
\text { scattered }\end{array}$ & $\begin{array}{l}\text { Extremely altered unit with a greenish color. } \\
\text { Rock is friable and fragments are sometime } \\
\text { difficult to recognise. Rich in juvenile } \\
\text { bombs. }\end{array}$ & $\mathrm{S} 1.1, \mathrm{~S} 1.2$ \\
\hline bTB1 & $\begin{array}{l}\text { Bedded tuff breccia, } \\
\text { lithic-rich }\end{array}$ & $\mathrm{dm}$ to $\mathrm{m}$ & $\begin{array}{l}\text { 10-30\%, } \\
\text { Lith }(\mathrm{Jm}>\mathrm{Tbl} \\
>\text { TRm, TRc) } \\
\text { >> Juv }\end{array}$ & $\begin{array}{l}55-60 \% \\
\text { Juv }>>\text { Lith } \\
(\mathrm{Jm}>\mathrm{Tbl}> \\
\text { TRm, TRc })\end{array}$ & $\begin{array}{l}10-22 \% \\
\text { mostly } \\
\text { coarse ash }\end{array}$ & $\begin{array}{l}3-5 \% \\
\text { patchy }\end{array}$ & $\begin{array}{l}\text { Mostly composed of grey juvenile clasts } \\
\text { (coarse ash to fine lapilli in size) (Fig. } 9 \mathrm{~b} \text { ). } \\
\text { Rich in juvenile bombs. Contains traces of } \\
\text { brown juvenile clasts. }\end{array}$ & $3,6, \mathrm{~S} 1.1$ \\
\hline
\end{tabular}

Fine ash $<250 \mu \mathrm{m}$, medium ash 250-500 $\mu \mathrm{m}$ and coarse ash $>500 \mu \mathrm{m}$ 


\begin{tabular}{|c|c|c|c|c|c|c|c|c|}
\hline $\begin{array}{l}\text { Facies } \\
\text { code }\end{array}$ & Name & $\begin{array}{l}\text { Column } \\
\text { width }\end{array}$ & $\begin{array}{l}\text { Blocks and } \\
\text { bombs }\end{array}$ & Lapilli & Ash & Cement & Comments & $\begin{array}{l}\text { Panoramas } \\
\left(\text { Fig. } n^{\circ}\right)\end{array}$ \\
\hline $\mathrm{n}(\mathrm{m}) \mathrm{LTh}$ & $\begin{array}{l}\text { Non-bedded } \\
\text { medium lapilli tuff, } \\
\text { heterolithic }\end{array}$ & $1-10 \mathrm{~m}$ & $\begin{array}{l}0-5 \%, \\
\text { Lith }>\text { Juv } \\
\text { to Juv }> \\
\text { Lith }(\mathrm{Jm} \geq \\
\text { Tbl }>\text { TRm })\end{array}$ & $\begin{array}{l}\text { 40-55\%, } \\
\text { Juv }>\text { Lith } \\
(\mathrm{Jm}>\mathrm{Tbl}> \\
\text { TRm, TRc) }\end{array}$ & $\begin{array}{l}32-58 \%, \\
\text { mostly fine } \\
\text { ash }\end{array}$ & $\begin{array}{l}0-10 \%, \\
\text { scattere } \\
\text { d to } \\
\text { patchy }\end{array}$ & $\begin{array}{l}\text { Mostly composed of ash and fine to medium lapilli } \\
\text { (Fig. 10a). Juvenile bombs versus blocks in equal } \\
\text { amounts. Traces of brown juvenile clasts, mainly of } \\
\text { fine lapilli size. Some lapilli-sized recycled tuff } \\
\text { fragments. }\end{array}$ & $3,4,7$ \\
\hline $\mathrm{n}(\mathrm{mc}) \mathrm{LTh} 1$ & $\begin{array}{l}\text { Non-bedded } \\
\text { medium to coarse } \\
\text { lapilli tuff, } \\
\text { heterolithic }\end{array}$ & $6-10 \mathrm{~m}$ & $\begin{array}{l}15-20 \% \\
\text { Lith }(\mathrm{Jm}> \\
\text { Tbl) } \geq \mathrm{Juv}\end{array}$ & $\begin{array}{l}50-55 \% \\
\text { Juv }>\text { Lith } \\
(\mathrm{Jm}>\mathrm{Tbl}> \\
\text { TRm })\end{array}$ & $\begin{array}{l}25-35 \% \\
\text { mostly fine } \\
\text { to medium } \\
\text { ash }\end{array}$ & $\begin{array}{l}\sim 1 \% \\
\text { scattere } \\
\text { d }\end{array}$ & $\begin{array}{l}\text { Mostly composed of medium to coarse lapilli-sized } \\
\text { lithic and juvenile fragments. Rare recycled tuff } \\
\text { fragments (Fig. 10b). Traces of brown juvenile } \\
\text { clasts. }\end{array}$ & 3, S1.1 \\
\hline $\mathrm{n}(\mathrm{mc}) \mathrm{LTh} 2$ & $\begin{array}{l}\text { Non-bedded } \\
\text { medium to coarse } \\
\text { lapilli tuff, } \\
\text { heterolithic }\end{array}$ & $4-20 \mathrm{~m}$ & $\begin{array}{l}5-10 \% \\
\text { Juv }>\text { Lith } \\
(\mathrm{Jm}>>\text { Tbl, } \\
\text { Trm, TRc) }\end{array}$ & $\begin{array}{l}\text { 50-70\%, } \\
\text { Juv >> Lith } \\
(\mathrm{Jm}>\text { Tbl, } \\
\text { Trm, TRc })\end{array}$ & $\begin{array}{l}17-40 \% \\
\text { mostly } \\
\text { medium to } \\
\text { coarse ash }\end{array}$ & $\begin{array}{l}3-10 \%, \\
\text { scattere } \\
\text { d to } \\
\text { patchy }\end{array}$ & $\begin{array}{l}\text { Mostly composed of medium to coarse lapilli-sized } \\
\text { lithic and juvenile fragments. Rare recycled tuff } \\
\text { fragments (Fig. 10b). Traces of brown juvenile } \\
\text { clasts. More juvenile bombs than juvenile and lithic } \\
\text { blocks. }\end{array}$ & $\begin{array}{l}4,7, \text { S1.1, } \\
\text { S1.3, S1.4 }\end{array}$ \\
\hline $\mathrm{n}(\mathrm{mc}) \mathrm{LTj}$ & $\begin{array}{l}\text { Non-bedded } \\
\text { medium to coarse } \\
\text { lapilli tuff, } \\
\text { juvenile-rich }\end{array}$ & $3-6 \mathrm{~m}$ & $\begin{array}{l}5-10 \% \\
\mathrm{Juv} \gg>\text { Lith } \\
(\mathrm{Jm} \gg>\mathrm{Tbl})\end{array}$ & $\begin{array}{l}50-55 \% \\
\text { Juv }>>\text { Lith } \\
(\mathrm{Jm}>\mathrm{Tbl}> \\
\text { TRm })\end{array}$ & $\begin{array}{l}10-35 \% \\
\text { mostly } \\
\text { coarse ash }\end{array}$ & $\begin{array}{l}10-25 \% \\
\text { scattere } \\
\text { d }\end{array}$ & $\begin{array}{l}\text { In figure } 4 \text {, unit is altered. In figure } \mathrm{S} 1.3 \text {, unit } \\
\text { crosscuts the entire outcrop like a vent would do it. } \\
\text { More juvenile blocks than juvenile bombs. Traces of } \\
\text { brown juvenile clasts. }\end{array}$ & 4, S1.3 \\
\hline $\mathrm{n}(\mathrm{c}) \mathrm{LTj}$ & $\begin{array}{l}\text { Non-bedded coarse } \\
\text { lapilli tuff, } \\
\text { juvenile-rich }\end{array}$ & $5-11 \mathrm{~m}$ & $\begin{array}{l}10-20 \% \\
\text { Juv }>>\text { Lith } \\
(\mathrm{Jm}>\mathrm{Tbl}> \\
\text { TRm })\end{array}$ & $\begin{array}{l}50-70 \% \\
\text { Juv }>>\text { Lith } \\
(\mathrm{Jm}>\mathrm{Tbl}> \\
\text { Trm, TRc })\end{array}$ & $\begin{array}{l}10-30 \% \\
\text { mostly } \\
\text { coarse ash }\end{array}$ & $\begin{array}{l}10-15 \% \\
\text { scattere } \\
\text { d }\end{array}$ & $\begin{array}{l}\text { Mostly composed of dark grey to black coarse lapilli } \\
\text { (Fig. 10c). More juvenile bombs than blocks; rare } \\
\text { lithic blocks. Can be altered (e.g., Fig. S1.1). Traces } \\
\text { of brown juvenile clasts. }\end{array}$ & $\begin{array}{l}\text { 4, S1.1, } \\
\text { S1.4 }\end{array}$ \\
\hline nTB1 & $\begin{array}{l}\text { Non-bedded, tuff } \\
\text { breccia, lithic-rich }\end{array}$ & $\sim 6 \mathrm{~m}$ & $\begin{array}{l}<50 \% \\
\text { Lith }(\mathrm{Jm}>> \\
\text { TRc }> \\
\text { TRm })>>> \\
\text { Juv }\end{array}$ & $\begin{array}{l}\sim 30 \% \\
\text { Juv }=\text { Lith } \\
(\mathrm{Jm}>\mathrm{TRm} \\
>\mathrm{TRc})\end{array}$ & $\begin{array}{l}\sim 20 \%, \\
\text { reddish, } \\
\text { Moenave- } \\
\text { rich, mostly } \\
\text { coarse ash }\end{array}$ & $0 \%$ & $\begin{array}{l}\text { Only one unit, extremely rich in Moenave Formation } \\
\text { clasts (Fig. 10d). Chinle and Moenkopi clasts are } \\
\text { represented whereas Bidahochi clasts are completely } \\
\text { absent. }\end{array}$ & 3 \\
\hline nTBh & $\begin{array}{l}\text { Non-bedded, tuff } \\
\text { breccia to coarse } \\
\text { lapilli tuff, } \\
\text { heterolithic }\end{array}$ & $4-17 \mathrm{~m}$ & $\begin{array}{l}15-30 \% \\
\mathrm{Juv} \geq \mathrm{Lith} \\
(\mathrm{Jm}>\mathrm{Tbl}> \\
\mathrm{Trm})\end{array}$ & $\begin{array}{l}50-60 \% \\
\text { Juv }>\text { Lith } \\
(\mathrm{Jm}>\mathrm{Tbl}> \\
\text { TRm }> \\
\text { TRc })\end{array}$ & $\begin{array}{l}8-28 \% \\
\text { mostly } \\
\text { coarse ash }\end{array}$ & $\begin{array}{l}5-10 \%, \\
\text { scattere } \\
\text { d to } \\
\text { patchy }\end{array}$ & $\begin{array}{l}\text { Mainly composed of coarse lapilli-sized lithic, } \\
\text { juvenile and tuff fragments (Fig. 10e, 10f). More } \\
\text { juvenile bombs than blocks. Great diversity of lithics } \\
\text { and traces of brown juvenile clasts. }\end{array}$ & $3,4, \mathrm{~S} 1.1$ \\
\hline
\end{tabular}

Juv = Juvenile clasts, Lith = Lithic clasts, Jm = Moenave Fm clasts, Tbl = Bidahochi Fm clasts, TRc = Chinle Fm clasts, TRm = Moenkopi Fm clasts

Fine ash $<250 \mu \mathrm{m}$, medium ash 250-500 $\mu \mathrm{m}$ and coarse ash $>500 \mu \mathrm{m}$ 